\title{
Konsep Pluralisme Hukum Khas Indonesia Sebagai Strategi Menghadapi Era Modernisasi Hukum
}

\author{
Fradhana Putra Disantara \\ Ilmu Hukum, Fakultas Ilmu Sosial dan Hukum, \\ Universitas Negeri Surabaya, Indonesia \\ dfradhana@gmail.com
}

\begin{abstract}
The purpose of this legal research is to describe the concept of Indonesian legal pluralism or Indonesian legal pluralism in facing the era of legal modernization; as well as describing the Indonesian legal pluralism strategy in integrating customary courts into the national legal system. This legal research uses a statute approach and a conceptual approach. In this legal research, the primary and secondary legal materials used are inventoried in order to obtain proper legal review; and provides a conceptual analysis of the legal issues discussed. The results of the study stated that as a novelty concept; The concept of typical Indonesian legal pluralism provides equality for the enactment of state law, transnational law and customary law so that they can run together based on the 1945 Constitution of the Republic of Indonesia in the era of legal modernization. Then, the concept of typical Indonesian legal pluralism can be used as a strategy to integrate customary justice into the national legal system through aspects of legal development. Thus, this research is expected to be useful theoretically; namely as a scientific development of customary law, and practical benefits; namely as a reference for drafting regulations on customary villages by local governments. Therefore, researchers recommend that the Indigenous Peoples Bill be a priority in the 2021 National Legislation Program (Prolegnas).
\end{abstract}

Keywords: Legal Pluralism; Indonesian Legal Pluralism; Customary law; Era of Legal Modernization

\begin{abstract}
Abstrak
Tujuan penelitian hukum ini adalah mendeskripsikan konsep Indonesian legal pluralism atau pluralism hukum khas Indonesia dalam menghadapi era modernisasi hukum; serta mendeskripsikan strategi Indonesian legal pluralism dalam mengintegrasikan peradilan adat dalam sistem hukum nasional. Penelitian hukum ini menggunakan metode statute approach dan conseptual approach. Pada penelitian hukum ini, bahan hukum primer dan sekunder yang digunakan diinventarisir agar mendapatkan kajian hukum yang semestinya; serta memberikan analisa konseptual atas isu hukum yang dibahas. Hasil penelitian menyatakan bahwa sebagai konsep kebaharuan; konsep pluralisme hukum khas Indonesia memberikan keseteraan atas berlakunya hukum negara, hukum transnasional, dan hukum adat agar dapat berjalan secara bersama-sama berdasarkan UUD NRI 1945 di era modernisasi hukum. Kemudian, konsep pluralisme hukum khas Indonesia dapat dijadikan sebagai strategi untuk
\end{abstract}


mengintegrasikan peradilan adat pada sistem hukum nasional melalui aspek pembinaan hukum. Dengan demikian, penelitian ini diharapkan dapat bermanfaat secara teoritis; yaitu sebagai pengembangan keilmuan hukum adat, dan bermanfaat secara praktis; yakni sebagai acuan untuk menyusun peraturan tentang desa adat oleh pemerintah daerah. Oleh karenanya, peneliti merekomendasikan agar RUU Masyarakat Adat menjadi prioritas dalam Program Legislasi Nasional (Prolegnas) 2021.

Kata Kunci: Pluralisme Hukum; Indonesian Legal Pluralism; Hukum Adat; Era Modernisasi Hukum

\section{A. Latar Belakang Masalah}

Masyarakat adat merupakan sekelompok masyarakat yang menempati wilayah tertentu serta mempraktikkan pranata-pranata hukum adat dan hanya berlaku di wilayah serta untuk masyarakat tertentu saja. ${ }^{1}$ Sejalan dengan asas lex est quaedam rationis ordinatio ad bonum commune, ab eo qui curam communitatis habet promulgata, hukum adat merupakan pemikiran bersama masyarakat adat sebagai upaya untuk menjaga tata nilai dan ajaran luhur dari para pendahulu untuk tetap eksis dan dilaksanakan. ${ }^{2}$ Oleh karena itu, masyarakat adat menempatkan hukum adat sebagai 'sarana' untuk menjaga nilai-nilai adat agar tetap lestari dan dapat dilaksanakan selaras dengan perkembangan zaman. ${ }^{3}$

Hukum adat sebagai sarana dan instrumen untuk menegakkan nilai-nilai adat ternyata menghadapi berbagai hambatan dan tantangan dalam pelaksanaannya $^{4}$. Setidaknya, terdapat dua hambatan dan tantangan dalam pemberlakuan hukum adat pada masyarakat. Pertama, semakin besarnya peran negara dalam kehidupan bermasyarakat membuat seolah-olah negara tampil dengan 'hukum formal' yang wajib ditaati dan dilaksanakan oleh masyarakat. Kedua, adanya fenomena globalisasi yang berdampak pada semua aspek

\footnotetext{
${ }^{1}$ Janos Jany, Legal Traditions in Asia: History, Concepts and Laws (Cham: Springer Nature, 2020).

2 E. Kofi Abotsi, "Customary Law and the Rule of Law," Arizona Journalof International \& Comparative Law 37, no. 2 (2020): 137-66.

3 Ingrida Žemaitèlytè-Ivanavičè, "The Confrontation of Education and Customary Law At School: The Case Of Roma," Journal of Education Culture and Society 11, no. 2 (September 11, 2020): 68-81.

${ }^{4}$ Paul Kuruk, Traditional Knowledge, Genetic Resources, Customary Law and Intellectual Property: A Global Primer (Cheltenham: Edward Elgar Publishing, 2020).
} 
kehidupan manusia dalam hal ini tidak terkecuali pula pada aspek hukum sehingga menghasilkan suatu fenomena baru bernama modernisasi hukum. Menurut Satjipto Rahardjo, ${ }^{5}$ modernisasi hukum merupakan 'gejala' yang diawali dengan adanya perkembangan teknologi yang masif yang diikuti dengan aspek digitalisasi pada segala lini aspek kehidupan manusia yang menjadi bersifat pasti dan mekanis, tak terkecuali juga dalam bidang hukum.

Maksim ut sementem faceris ita metes nyatanya memberikan refleksi atas berbagai fenomena modernisasi hukum; ${ }^{6}$ yang dibuktikan oleh catatan Yayasan Lembaga Bantuan Hukum Indonesia tahun 2019, terjadi konflik agraria wilayah adat pada luasan tanah sekitar 488.407 hektar yang terbagi di 16 provinsi karena adanya pembangunan infrastruktur. ${ }^{7}$ Laporan Aliansi Masyarakat Adat Nusantara, menyatakan sekitar 313.000 hektar tanah adat tumpang tindih dengan berbagai izin konsesi yang tersebar pada 307 komunitas masyarakat adat. ${ }^{8}$ Bahkan, terjadi pertentangan antara aparatur desa administratif dengan praktik hukum adat sebagaimana yang terjadi pada masyarakat adat Malind-Anim di Merauke; ${ }^{9}$ serta masyarakat adat Rejang Lebong di Bengkulu. ${ }^{10}$

Di era modernisasi hukum, hukum yang semestinya merupakan kristalisasi dari asas dan nilai moral masyarakat kemudian berubah menjadi sesuatu yang formal, pasti, tekstual, serta adanya pemaksaan dari aparatur negara. ${ }^{11}$ Oleh karena itu, modernisasi hukum menyebabkan adanya dikotomi antara hukum negara dan

\footnotetext{
${ }^{5}$ Satjipto Rahardjo, Membedah Hukum Progresif (Jakarta: Penerbit Buku Kompas, 2006).

${ }^{6}$ Jedediah Britton-Purdy et al., "Building a Law-and-Political-Economy Framework: Beyond the Twentieth-Century Synthesis," Yale Law Journal 129, no. 6 (2020): 1786-1832.

7 Andre Barahamin, "Bongku Dan Pengabaian Hak Masyarakat Adat," mongabay.co.id, 2020.

8 Erafzon Saptiyulda, "Buka Dokumen HGU Untuk Tuntaskan Persoalan Tata Kelola Hutan," antaranews.com, 2019.

${ }^{9}$ Ahyuni Yunus and Ahmad Ali Muddin, "Penyelesaian Sengketa Tanah Ulayat Yang Telah Bersertifikat Berdasarkan Hukum Adat Malind-Anim," Jurnal Kertha Patrika 41, no. 3 (2019): 206.

${ }^{10}$ JT Pareke and Fahmi Arisandi, "Pengakuan Masyarakat Hukum Adat dan Perlindungan Wilayah Adat di Kabupaten Rejang Lebong," Bina Hukum Lingkungan 4, no. 2 (April 26, 2020): 313.

${ }^{11}$ Nevin Johnson, “Legality's Law's Empire," Law and Philosophy 39, no. 3 (June 23, 2020): 325-49.
} 
hukum non negara. Hukum negara disebut sebagai 'hukum resmi',12 sedangkan hukum non negara (termasuk hukum adat) sebagai 'hukum tidak resmi'. ${ }^{13}$ Bahkan, substansi 'hukum resmi' yang dibuat oleh negara terkadang mengesampingkan serta bertentangan dengan norma-norma hukum adat serta kebiasaan yang telah dipraktikkan secara kontinu oleh masyarakat. ${ }^{14}$

Dengan demikian, diperlukan suatu konsep untuk mensejajarkan keberadaan hukum adat dengan hukum nasional; agar tidak terdapat norma hukum adat maupun hukum negara yang terdelegitimasi baik secara materiil maupun formil. Oleh karenanya, penulis merekomendasikan strategi Indonesian legal pluralism dalam menghadapi era modernisasi hukum. Konsep Indonesian legal pluralism atau pluralisme hukum khas Indonesia merupakan konsep kebaharuan dari konsep triangular concept of legal pluralism yang dikemukakan oleh Werner Menski. Pluralisme hukum khas Indonesia yang diharapkan dapat memberikan harmonisasi serta integrasi terhadap hukum negara, hukum transnasional, dan hukum adat, sehingga dapat berlaku secara bersamaan, beriringan, serta saling melengkapi.

Melalui konsep kebaharuan di atas, dapat dioptimalkan untuk mengintegrasikan salah satu elemen penting hukum adat; yaitu peradilan adat. Hadirnya peradilan adat cenderung merupakan hasil transplantasi konstitusi; sehingga lembaga-lembaga adat yang melakukan proses sengketa sebagai lokus hukum dalam pemeliharaan tatanan sosial ini harus tetap dilestarikan. Di sisi lain, peradilan adat memiliki manajemen perselisihan yang berfokus pada penggunaan hukum oleh pihak yang berperkara untuk mencapai tujuan mereka sendiri, daripada pada peran hukum dalam menjaga tatanan sosial.

Penelitian hukum ini bertujuan untuk mendeskripsikan konsep Indonesian legal pluralism dalam menghadapi era modernisasi hukum; serta mendeskripsikan

\footnotetext{
${ }^{12}$ William Lucy, "Access to Justice and the Rule of Law," Oxford Journal of Legal Studies 40, no. 2 (June 1, 2020): 377-402.

13 Putri Fransiska Purnama Pratiwi, Suprayitno, and Triyani, "Existence of Customary Law through Comparative Education between Dayak Ngaju Customary Law and National Law," Budapest International Research and Critics Institute (BIRCI-Journal) : Humanities 3, no. 2 (2020).

14 Guillaume Tusseau, ed., Debating Legal Pluralism and Constitutionalism: New Trajectories for Legal Theory in the Global Age (New York: Springer Nature, 2020).
} 
strategi Indonesian legal pluralism dalam mengintegrasikan peradilan adat dalam tataran sistem hukum nasional. Manfaat penelitian ini terbagi atas dua hal; yakni manfaat secara teoritis dan secara praktis. Manfaat teoritis penelitian hukum ini adalah sebagai bentuk pengembangan keilmuan hukum adat berupa kebaharuan konsep pluralisme hukum, yaitu Indonesian legal pluralism. Sedangkan manfaat secara teoritis penelitian hukum ini adalah menjaga eksistensi hukum adat dalam tataran sistem hukum yang berlaku; serta diharapkan penelitian ini dapat dijadikan acuan penyusunan peraturan tentang desa adat oleh pemerintah daerah.

\section{B. Metode Penelitian}

Jenis penelitian berjudul Konsep Pluralisme Hukum Khas Indonesia sebagai Strategi Menghadapi Era Modernisasi Hukum merupakan legal research atau penelitian hukum. Penelitian hukum merupakan serangkaian usaha untuk memperoleh kebenaran koherensi; dengan mengidentifikasi relevansi antara peraturan yang berlaku dengan norma yang termaktub, relevansi prinsip hukum terhadap norma peraturan, dan keselerasan atas tindakan hukum terhadap prinsip atau norma hukum. ${ }^{15}$ Penelitian hukum ini menggunakan metode pendekatan conceptual approach) dan statue approach. Selanjutnya, penelitian ini menggunakan bahan hukum primer berupa peraturan perundang-undangan. ${ }^{16} \mathrm{Di}$ samping itu, Peneliti menggunakan bahan hukum sekunder pula; berbagai bahan sekunder tersebut berupa jurnal nasional maupun internasional, buku, disertasi, prosiding, tesis, dan karya hukum lainnnya. Kedua bahan hukum di atas dikumpulkan oleh peneliti dengan menggunakan metode studi kepustakaan. Melalui metode ini, peneliti menginventarisir bahan hukum primer maupun sekunder guna memperoleh preskripsi. ${ }^{17}$ Selanjutnya, peneliti melakukan analisa data menggunakan pola deduksi; sehingga peneliti menjelaskan berbagai norma

\footnotetext{
${ }^{15}$ Peter Mahmud Marzuki, Penelitiam Hukum, 13th ed. (Jakarta: Kencana, 2017).

${ }^{16}$ Shubhan Shodiq, "Penanganan Covid-19 Dalam Pendekatan Kaidah Fikih Dan Ushul Fikih (Analisis Kebijakan Pembatasan Sosial Berskala Besar Dibidang Keagamaan)," Al-Adalah: Jurnal Hukum Dan Politik Islam 5, no. 2 (July 16, 2020): 100-122.

17 Zulkifli Aspan and Wiwin Suwandi, "Menjerat Kader, Melepas Partai Politik; Pertanggungjawaban Pidana Partai Politik Dalam Kasus Tindak Pidana Korupsi," Al-Adalah: Jurnal Hukum Dan Politik Islam 5, no. 1 (April 30, 2020): 57-78.
} 
peraturan dalam kaitannya dengan isu hukum terlebih dahulu, lalu menjelaskan tentang fakta hukum kemudian. ${ }^{18}$ Analisa data tersebut disusun secara saksama, sistematis, teratur, logis; dan dideskripsikan secara komprehensif, holistik, dan rinci. Dengan demikian, pola penalaran tersebut disusun secara sistematis hingga tercapai suatu kesimpulan.

\section{Hasil Penelitian dan Pembahasan}

\section{Konsep Indonesian Legal Pluralism dalam Menghadapi Era}

\section{Modernisasi Hukum}

Bangsa Indonesia terdiri dari berbagai suku bangsa; yang melahirkan local genius. ${ }^{19}$ Hal tersebut merupakan konsekuensi atas kemajemukan adat yang hidup dan berkembang dalam berbagai ragam tradisi dan budaya. ${ }^{20}$ Bukan hanya itu, Indonesia adalah negara yang majemuk secara hukum. ${ }^{21}$ Tidak hanya karena Indonesia menampung berbagai kelompok suku yang memiliki berbagai tatanan normatif yang hidup berdampingan, tetapi juga karena negara tersebut telah memiliki sistem hukum nasional; ${ }^{22}$ yang disetujui secara konstitusional (UUD NRI 1945) yang berdampingan dengan tatanan normatif lainnya. Implikasinya, terjadi perubahan sosial yang mengkonstruksikan suatu tatanan organisasi sosial dalam bentuk hukum adat; ${ }^{23}$ sebagai bentuk perlindungan hidup bagi masyarakat adat.

Tentunya, masing-masing masyarakat adat tentu memiliki hukum adat yang berbeda satu sama lain. Maka dari itu, prinsip consuetudo pro lege servatur mendasari manifestasi local genius dalam bentuk hukum adat. Seiring berjalannya waktu, keberadaan hukum adat sedikit demi sedikit dipengaruhi secara internal

${ }^{18}$ Marzuki, Penelitiam Hukum.

$19 \mathrm{Rr}$ Catharina Dewi Wulansari, Hukum Adat Indonesia - Suatu Pengantar, 4th ed. (Bandung: PT Refika Aditama, 2016).

${ }^{20}$ RR. Catharina Dewi Wulansari, "The Role of The Government in The Recognition of Customary Rights to Achieve Economic Development of Customary Law Communities," Journal of Indonesian Adat Law (JIAL) 1, no. 1 (October 15, 2020): 109-45.

${ }^{21}$ Mulyono Mulyono, Dewi Setyowati, and Kamarudin Kamarudin, "Tanggung Jawab Hukum Atas Pasien Gangguan Jiwa Yang Melarikan Diri Dari Ruang Rawat Inap Rumah Sakit," AlAdalah: Jurnal Hukum Dan Politik Islam 3, no. 1 (July 3, 2019): 56-65.

22 Fradhana Putra Disantara, "The Large Scale Social Restrictions Policy For Handling The COVID-19 Pandemic," Jurnal Pembaharuan Hukum 7, no. 2 (2020): 128-41.

${ }^{23}$ Wayan P. Windia et al., "Bunga Rampai APHA Indonesia: Melihat Covid-19 Dari Perspektif Hukum Adat," Journal of Indonesian Adat Law (JIAL) 1, no. 1 (2020): 373. 
maupun eksternal; tak terkecuali oleh hukum luar -hukum nasional-. Oleh karenanya, lahir konsep legal pluralism guna menjaga hakikat dari 'hukum' itu sendiri. $^{24}$

Sejatinya, konsep pluralisme hukum merupakan kondisi manakala terdapat dua atau lebih sistem hukum yang sedang berjalan dan hidup berdampingan pada dimensi sosial yang sama pula. Teori tersebut menegaskan bahwa norma adat/norma sosial, norma negara (hukum negara), dan hukum agama/etika dapat dijalankan bersama-sama; ${ }^{25}$ yang bertujuan secara optimal untuk menjalin interaksi satu sama lain diantara ketiga norma tersebut. ${ }^{26}$ Pluralisme hukum adalah serangan terhadap sentralisme hukum; ${ }^{27}$ yakni gagasan bahwa hukum adalah satu-satunya lembaga formal negara. Adapula anggapan; bahwa pluralisme hukum adalah cara untuk mengkritik kekuasaan negara dan bahkan terkadang merayakan perlawanan terhadap hegemoni negara. ${ }^{28}$ Berikut skema dari konsep legal pluralism:

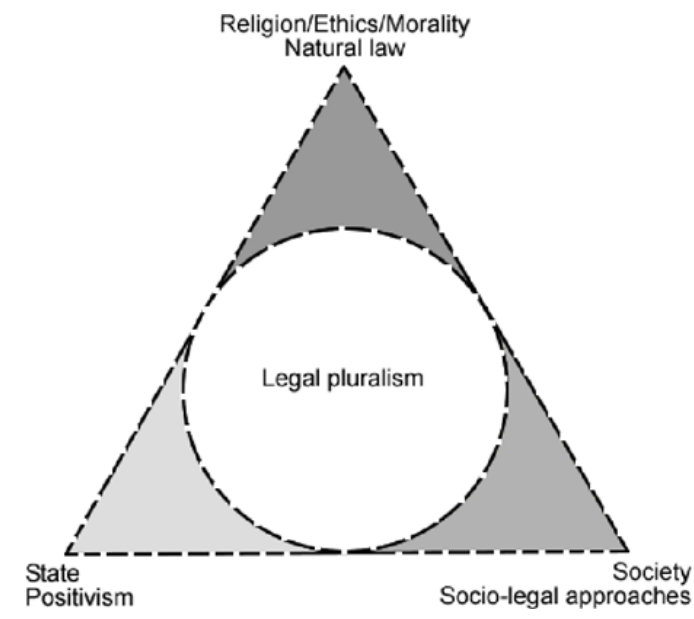

Gambar 1. Tiga norma utama yang berlaku dalam pluralisme hukum. ${ }^{29}$

\footnotetext{
${ }^{24}$ Pedro Naso, Erwin Bulte, and Tim Swanson, "Legal Pluralism in Post-Conflict Sierra Leone," European Journal of Political Economy 61 (January 2020): 1-21.

${ }^{25}$ Werner F. Menski, Comparative Law in a Global Context: The Legal Systems of Asia and Africa, Comparative Law in a Global Context: The Legal Systems of Asia and Africa, Second Edition, 2nd ed. (Cambridge: Cambridge University Press, 2006).

26 Tomáš Ledvinka, "The Disenchantment of the Lore of Law: Jacob Grimm's Legal Anthropology Before Anthropology," The Journal of Legal Pluralism and Unofficial Law 52, no. 2 (May 3, 2020): 203-26.

${ }_{27}$ Naso, Bulte, and Swanson, "Legal Pluralism in Post-Conflict Sierra Leone."

28 Georges Gharios, "Legal Pluralism and Un-Official Law in Lebanon: Evolution and Sustainable Development of Water," Water Policy 22, no. 3 (June 1, 2020): 348-64.

${ }^{29}$ Menski, Comparative Law in a Global Context: The Legal Systems of Asia and Africa.
} 
Konsep di atas dikukuhkan oleh Werner Menski atas kajian strategis tentang perbedaan dan komparasi antara keberadaan hukum di negara Asia dan Afrika dengan hukum di wilayah Eropa. Tatanan hukum di wilayah eropa cenderung bersifat rasionalis-logis; ${ }^{30}$ yang melepaskan faset agama dan moralitas di dalam norma maupun penegakan hukum. Fakta tersebut berbeda dengan keberadaan hukum dalam lingkaran masyarakat yang pluralistik seperti halnya di Asia maupun Afrika; ${ }^{31}$ yang lebih mengutamakan aspek perasaan manusia sebagai pengaruh dari moralitas, agama, dan etika.

Dengan demikian, garis demarkasi hukum antara kedua benua tersebut sangat wajar apabila terjadi; mengingat karakter hukum setiap negara atau wilayah memiliki esensi tersendiri. Meskipun demikian, konsep pluraslime hukum didefinisikan ulang oleh masing-masing negara. Mengapa demikian? Karena setiap negara sungguh tidak mungkin dapat membangun segala aspek kebaharuan termasuk pembangunan hukum- secara mandiri tanpa adanya pengaruh -baik disengaja maupun tidak- era modernisasi hukum sebagai implikasi adanya globalisasi. $^{32}$

Era modernisasi hukum merupakan kondisi manakala perkembangan teknologi dan informasi memberikan implikasi pada kuantitas dan kualitas hukum adat $^{33}$ sehingga aspek kehidupan manusia menjadi pasti dan mekanis, tidak terkecuali hukum adat. $^{34}$ Fenomena modernisasi hukum dimaknai sebatas dokumen legal-formal yang bersifat tertulis dan bersifat memaksa. Padahal maksim certum est quod is committit in lege, qui legis verbum complectens, contra

\footnotetext{
${ }^{30}$ Yuval Sinai and Benjamin Shmueli, Maimonides and Contemporary Tort Theory: Law, Religion, Economics, and Morality (Cambridge: Cambridge University Press, 2020).

${ }^{31}$ Neilesh Bose and Victor V. Ramraj, "Lex Mercatoria, Legal Pluralism, and the Modern State through the Lens of the East India Company, 1600-1757," Comparative Studies of South Asia, Africa and the Middle East 40, no. 2 (August 1, 2020): 277-90.

${ }^{32} \mathrm{Rr}$ Catharina Dewi Wulansari and Yenny Yorisca, "Persoalan-Persoalan Kontemporer Dalam Ilmu Hukum," Ajudikasi : Jurnal Ilmu Hukum 4, no. 1 (2020): 83-98.

${ }^{33}$ Miguel De Lemos, "Legal Pluralism And International Development: Introductory Notes On The Dialogue Between The Two Concepts.," Humanities And Rights | Global Network Journal 2, no. 1 (June 24, 2020): 190-233.

${ }^{34}$ Rahardjo, Membedah Hukum Progresif.
} 
legis nititur voluntatem memberikan nasihat agar masyarakat tidak salah menafsirkan hukum. ${ }^{35}$

Era modernisasi hukum mendorong adanya mobilitas sumber daya manusia dari satu tempat ke tempat lain; yang melahirkan perubahan -yang disebabkan oleh manusia pula- atas segala dimensi kehidupan manusia, tak terkecuali hukum. ${ }^{36}$ Oleh sebabnya, lahirlah suatu hukum yang dipengaruhi dari berbagai arah dan penjuru dunia yang memasuki wilayah ruang suatu negara secara tanpa batas; dan terus bergerak menyasar kepada seluruh sumber daya manusia yang ada. Dengan demikian, terjadi interaksi, adopsi, persentuhan, dan kontestasi antara hukum nasional di era modernisasi hukum dengan hukum adat dalam konteks sosio-politik tertentu.

Quando duo jura di una persona concurrunt, aequum est acsi essent deversis; seperti halnya hukum negara dan hukum adat memiliki tujuan yang sama, namun kedua hal tersebut berbeda. Hukum adat mengedepankan aspek kontekstual dengan menggunakan pendekatan sosial dan lokal yang didasarkan pada nilai-nilai etika dan moral yang tumbuh dan berkembang di masyarakat. ${ }^{37}$ Sedangkan hukum negara didasarkan atas aspek tekstual berupa bangunan peraturan dengan pendekatan prosedural administratif. ${ }^{38}$ Dengan demikian, diperlukan upaya persentuhan untuk memberikan kekuatan legitimasi satu sama lain.

Apabila tidak melakukan adopsi maupun persentuhan, maka hukum adat dikhawatirkan semakin tersisih di negeri kita sendiri. Hal ini sejalan dengan teori competitive advandtages $;{ }^{39}$ yang menyatakan apabila eksistensi hukum adat tidak memiliki kemampuan untuk bersaing, maka hukum adat akan semakin tertinggal. Konsep pluraslime hukum dalam perspektif yang baru melahirkan koeksistensi

\footnotetext{
${ }^{35}$ Pnina Werbner and Richard Werbner, “Adultery Redefined: Changing Decisions of Equity in Customary Law as 'Living Law' in Botswana," PoLAR: Political and Legal Anthropology Review 43, no. 1 (May 11, 2020): 136-52.

${ }^{36}$ Bose and Ramraj, "Lex Mercatoria, Legal Pluralism, and the Modern State through the Lens of the East India Company, 1600-1757."

37 Teuku Muttaqin Mansur, Sulaiman Sulaiman, and Hasbi Ali, "Adat Court in Aceh, Indonesia: A Review of Law," Jurnal IImiah Peuradeun 8, no. 2 (May 30, 2020): 423.

${ }^{38}$ Peter G. Staubach, The Rule of Unwritten International Law: Customary Law, General Principles, and World Order (Milton Park: Taylor \& Francis, 2020).

${ }^{39}$ Hanisah Binte Abdullah Sani, "State Law and Legal Pluralism: Towards an Appraisal," The Journal of Legal Pluralism and Unofficial Law 52, no. 1 (January 2, 2020): 82-109.
} 
hukum negara, hukum internasional -sebagai konsekuensi globalisasi-, dan hukum transnasional. ${ }^{40}$

Hukum transnasional membawa berbagai norma internasional, seperti norma hak asasi manusia internasional. ${ }^{41}$ Sebenarnya, hal tersebut dapat memperkuat aspek demokrasi negara apabila dipahami dengan baik. ${ }^{42}$ Hal tersebut dikarenakan demokrasi konstitusional telah memasukkan gagasan bahwa semua orang (dan bukan hanya mayoritas) dapat berpartisipasi secara aktif dalam pembangunan nasional. Jadi, ketaatan pada norma-norma internasional -yang minimal melindungi kepentingan minoritas atau lembaga multilateral- membantu pemerintah untuk mengakomodasi hak-hak konstitusional dari warga negara. Tak ayal, tercipta hukum transnasional sebagai konsekuensi atas terjadinya adaptasi hukum serta pemenuhan kepentingan akan kerjasama antar bangsa. ${ }^{43}$ Maka dari itu, konsep legal pluralism harus diperbaharui dengan adanya persentuhan dan penyesuaian diri atas keberadaan antara hukum adat dengan hukum nasional. ${ }^{44}$

Lalu, mengapa pluralisme hukum hendaknya menempatkan hukum transnasional sejajar dengan hukum negara dan hukum adat? Hal ini dikarenakan untuk melayani banyak agenda politik luar negeri dari negara; yang dapat dilihat sebagai program politik suatu negara. Dengan demikian, hendaknya terdapat keterikatan antara hukum transnasional dan budaya bangsa; yang dapat mengungkapkan bahwa praktik regulasi internasional berakar pada prinsip moralitas nasional. ${ }^{45}$ Hal ini menandai adanya proses memasukkan prinsip-prinsip

\footnotetext{
${ }^{40}$ Dimitri Van Den Meerssche and Geoff Gordon, “'A New Normative Architecture' - Risk and Resilience as Routines of Un-Governance," Transnational Legal Theory 11, no. 3 (July 2, 2020): 267-99.

${ }^{41}$ Johanna Del Pilar Cortés-Nieto, "Transnational Law and Development as a Means to Reshape States and Rights," Journal of Law and Society 47, no. 4 (November 10, 2020): 694-701.

42 Tom Ginsburg, "Authoritarian International Law?," American Journal of International Law 114, no. 2 (April 3, 2020): 221-60.

43 Filiz Kahraman, Nikhil Kalyanpur, and Abraham L. Newman, "Domestic Courts, Transnational Law, and International Order," European Journal of International Relations 26, no. 1 (September 28, 2020): 184-208.

44 Sulastriyono Sulastriyono, "Adat Law as An Alternative Option In Law Pluralism Perspective In Indonesia," Journal of Indonesian Adat Law (JIAL) 1, no. 1 (October 15, 2020): 3462.

${ }^{45}$ Angeliki Samara, Beyond the Responsibility to Protect in International Law: An Ethics of Irresponsibility (New York: Routledge, 2020).
} 
kebudayaan dalam berbagai preskripsi normatif; ${ }^{46}$ yang berhubungan dengan berbagai aspek kehidupan manusia, seperti ekonomi, pembangunan, dan bidang hukum transnasionalisasi lainnya.

Dengan hadirnya hukum transnasional, negara dapat mengadopsi definisi hukum dan otoritas seluas mungkin untuk menegaskan bahwa hukum sebagai bagian dari percakapan internasional yang tidak akan pernah berakhir. ${ }^{47}$ Bagaimanapun, hukum bukan hanya aturan, tetapi seperangkat praktik intelektual, sosial, politik, dan etika yang kompleks. Oleh karenanya, hukum transnasional dapat membentuk seperangkat institusi, prosedur, dan praktik sosial dengan menghormati, mengakui, dan mengadopsi nilai-nilai afiliasi komunitas adat untuk mewujudkan solusi yang yurisgeneratif. Tantangan pengelolaan sumber daya lokal yang ditimbulkan oleh intervensi hukum transnasional akan ditangani sebagai masalah tekno-legal; yang dapat diselesaikan dengan memperhatikan kebudayaan lokal, sekaligus mengacu pada standar normatif yang mengglobal. Untuk itu, dibutuhkan konsep pluralisme hukum yang memperhatikan kebutuhan untuk mengakui, mendukung, dan mengembangkan beragam bentuk otoritas dan kehidupan asosiasi lokal

Dengan demikian, di Indonesia; konsep pluralisme hukum hendaknya tidak serta merta diimplementasikan secara sepenuhnya. Oleh karenanya, konsep pluralism hukum khas Indonesia wajib dikehendaki sebagai dasar fundamental integrasi berbagai sistem hukum yang ada pada era saat ini. Konstruksi konsep pluralisme hukum ala Indonesia atau Indonesian legal pluralism dapat dilakukan dengan menambahkan berbagai teori maupun konsep lain agar menciptakan teori pluralisme hukum yang khas dari Indonesia. Hal tersebut dapat ditunjukkan manakala natural law, transnational law, dan positive law diberlakukan secara bersama dengan berbasis atas Undang Undang Dasar Negara Republik Indonesia tahun 1945 (UUD NRI 1945) dan visi misi dari Negara Kesaturan Republik Indonesia, khususnya alinea keempat IV.

\footnotetext{
${ }^{46}$ Jennifer L. Schulz, Mediation \& Popular Culture (New York: Routledge, 2020).

${ }^{47}$ Hasbi Aswar, Danial Bin Mohd. Yusof, and Rohana Binti Abdul Hamid, "Conflict Between Hizb Ut-Tahrir And Islamic Civil Society In Indonesia:A Countermovement Approach," Al-Adalah: Jurnal Hukum Dan Politik Islam 5, no. 2 (July 30, 2020): 171-91.
} 
Mengapa demikian? tujuan negara menjadi prinsip fundamental pluralisme hukum khas Indonesia agar tidak terjadi orientasi hukum tunggal yang didorong menjadi hukum yang paling kuat. Oleh karena itu, tujuan negara sebagai kerangka pluralisme hukum di Indonesia berfungsi agar menciptakan seluruh sistem hukum memiliki legitimasi yang sama kuat dan kedudukan yang sejajar. Berikut skema dari Indonesian legal pluralism:

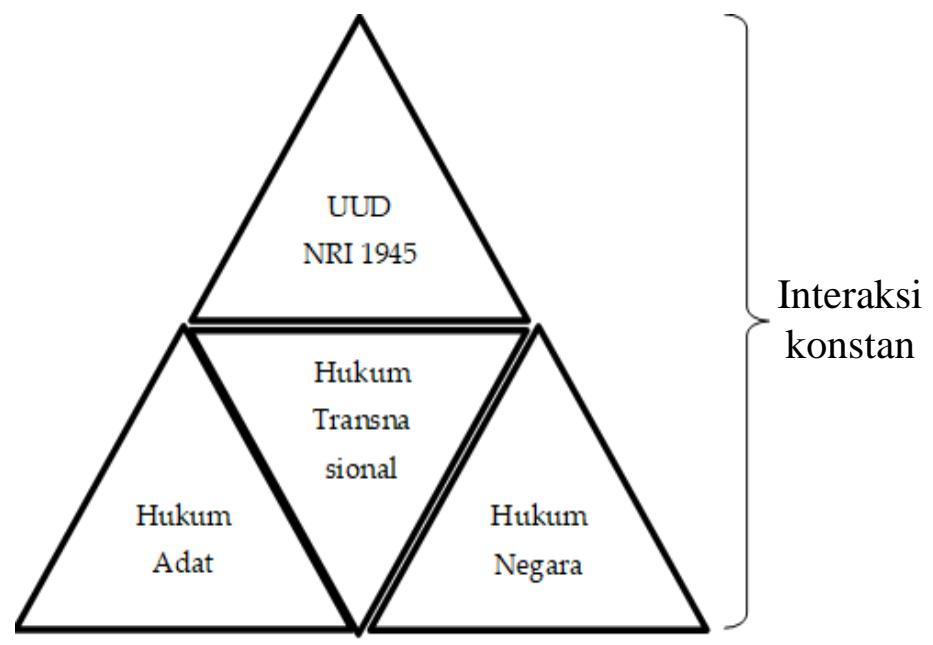

Gambar 2. Tiga hukum yang berlaku dalam pluralisme hukum khas Indonesia dengan basis UUD NRI 1945

Pluralisme hukum khas Indonesia menerapkan suatu cakrawala sosio-legal dengan mengalihkan perspektif normatif ke arah sesuatu yang bersifat empiris melalui tindakan kolektif yang dilembagakan. Pluralisme hukum khas Indonesia akan mendorong munculnya rasa kewajiban bagi masyarakat yang mengikat cara praktis agar tunduk kepada sistem hukum yang berjalan bersama dalam waktu yang sama pula.

Indonesian legal pluralism memberikan kesempatan adanya interaksi konstan antara sistem hukum tersebut. Hal ini dikarenakan otoritas resmi dan yurisdiksi dari setiap sistem hukum tidak akan pernah mutlak. Maknanya, tidak akan pernah ada masyarakat pada suatu negara yang mentaati pada sistem hukum 
yang sama. ${ }^{48}$ Namun, kita harus mempelajari kontestasi antara tiga sistem hukum tersebut dengan meninjau norma-norma peraturan yang berlaku, menganalisa pengaruh dari sistem hukum tersebut, dan mencoba untuk meningkatkan kesadaran hukum masyarakat waktu ke waktu atas adanya perbedaan dari setiap sistem hukum yang ada. Perubahan dalam kesadaran hukum tersebut dapat dipengaruhi oleh norma-norma yang diartikulasikan; ${ }^{49}$ yang bersandar pada nilai-nilai moral dan keadilan.

Konsep dari pluralisme hukum adalah bahwa norma-norma yang dibuat di luar kerangka pembuatan hukum negara juga dapat dianggap sebagai 'hukum; ${ }^{50}$ atau masyarakat atau individu. Namun, meskipun keberadaan dari 'hukum' non negara diakui; negara masih dianggap sebagai superior dari tatanan hukum lainnya. ${ }^{51}$ Berbeda dengan hal tersebut, pluralisme hukum khas Indonesia tidak menginginkan suatu sistem hukum tunduk pada hirarki tertentu; yang dianggap merendahkan atau memperlakukan sistem hukum tertentu sebagai inferior.

Di sisi lain, secara empiris; pluralisme hukum khas Indonesia melahirkan interaksi konstan antara tatanan hukum dengan nilai-nilai moral yang tumbuh di masyarakat. Nilai-nilai moral tersebut dapat tercermin pada butir-butir Pancasila sebagai panduan sikap dan tindakan daripada masyarakat. ${ }^{52}$ Pluralisme hukum khas Indonesia menentukan validitas nilai dan norma sebagai hukum melalui visi misi tujuan negara serta butir-butir Pancasila. Hal tersebut dilakukan agar terjadi interaksi antara norma-norma yang berbeda; guna menciptakan ketiga sistem hukum yang berdampingan dan sejajar.

\footnotetext{
${ }^{48}$ Jennifer Corrin, "Plurality and Punishment: Competition Between State and Customary Authorities in Solomon Islands," The Journal of Legal Pluralism and Unofficial Law 51, no. 1 (January 2, 2019): 29-47.

${ }^{49}$ Christopher J. Insole, Kant and the Divine: From Contemplation to the Moral Law (New York: Oxford University Press, 2020).

50 Emma Charlene Lubaale, "Legal Pluralism As a Lens Through Which to Understand The Role and Place of Tjms in International Criminal Justice," The Journal of Legal Pluralism and Unofficial Law 52, no. 2 (May 3, 2020): 180-202.

${ }^{51}$ Eduardo C. B. Bittar, "Semiotics of Law, Juridicity and Legal System: Some Observations and Clarifications of a Theoretical Concept," International Journal for the Semiotics of Law 1, no. 1 (November 11, 2020): 1-24.

52 Fradhana Putra Disantara, "The Legitimacy of Circular Letter in Handling COVID-19 Pandemic," Rechtsidee 6, no. 2 (2020): 1-10.
} 
Demikian pula, fleksibilitas yang melekat dalam struktur pluralis konsep pluralism hukum khas Indonesia dapat menjadi sumber stabilitas; karena ketegangan dalam tatanan sosial memiliki ruang untuk dimainkan dalam struktur pemerintahan hukum itu sendiri. Hal tersebut berbeda pada konsep legal pluralism; karena struktur hierarki yang berorientasi pada hukum negara tidak memiliki fleksibilitas untuk beradaptasi terhadap perubahan, tantangan, dan kontestasi global. ${ }^{53}$ Pluralisme hukum khas Indonesia memberikan celah bagi banyak suara yang mungkin tidak dimiliki oleh institusi yang lebih berbasis hierarki. Maka dari itu, kita mungkin menemukan struktur pluralis lebih stabil daripada struktur hierarkis dari waktu ke waktu.

Dengan demikian, apabila nilai-nilai yang terkandung dalam ketiga sistem hukum tersebut dapat berjalan beriringan; maka akan timbul pemahaman terhadap masyarakat atas 'apa' yang harus mereka lakukan dan 'apa' yang mereka tidak harus lakukan. Konsep Indonesian legal pluralism sejalan dengan pendapat Guillaume Tusseau, ${ }^{54}$ yang menyatakan bahwa teori pluralisme hukum harus disesuaikan dengan kondisi setempat agar melahirkan ruang untuk interaksi yang produktif di antara berbagai lapisan masyarakat dan sistem hukum yang tumpang tindih dengan mengembangkan mekanisme prosedural, lembaga, dan praktik yang bertujuan untuk membawa komunitas dan sistem tersebut ke dalam posisi yang seimbang.

Konsep Indonesian legal pluralism mengasumsikan bahwa ketiga sistem hukum di atas merupakan seluruh rangkaian legalitas yang mengalir melalui pengalaman sehari-hari masyarakat. Masyarakat memainkan peran penting dalam mengarahkan interaksi ketiga sistem hukum di atas; dan menggunakan kolaborasi sistem tersebut secara strategis. Hal tersebut dilakukan dengan mengkaji normanorma hukum untuk mengkonseptualisasikan interaksi dari semua pernyataan norma yang beragam dari ketiga sistem di atas; sekalipun hukum nasional dan transnasional sarat dengan sistem normatif dan tuntutan yurisdiksi yang

\footnotetext{
53 Svein Jentoft and Maarten Bavinck, "Reconciling Human Rights and Customary Law: Legal Pluralism in The Governance of Small-Scale Fisheries," The Journal of Legal Pluralism and Unofficial Law 51, no. 3 (September 2, 2019): 271-91.

54 Tusseau, Debating Legal Pluralism and Constitutionalism: New Trajectories for Legal Theory in the Global Age.
} 
dikeluarkan oleh berbagai entitas pemerintah dan non pemerintah. ${ }^{55}$ Dengan demikian, konsep pluralisme hukum khas Indonesia memberikan ruang untuk mengevaluasi dan merancang lembaga dan prosedur hukum yang ada; kemudian dikaitkan dengan didasarkan UUD NRI 1945 untuk mencapai tujuan keadilan yang substantif.

Lahirnya konsep Indonesian legal pluralism juga dilatar belakangi oleh beberapa 'kekurangan' dari konsep legal pluralism. Pertama. Legal pluralism tidak memiliki standar etika dan moral yang jelas. ${ }^{56}$ Tak ayal, konsep pluralisme hukum cenderung berbenturan dengan visi dan tujuan negara; ${ }^{57}$ pada tataran pemikiran, makna, dan aktualisasi. Harus dimengerti, bahwa konsep tujuan suatu negara yang merupakan "kesepakatan tentang hal-hal yang fundamental atas nilainilai etika dan moral" yang tidak dapat dipersamakan satu sama lain. ${ }^{58}$ Perihal tersebut, berbagai pihak telah terlibat untuk memberikan gagasan -yang berbedabeda- tentang visi-misi negara untuk mewujudkan negara kesejahteraan dengan menegakkan moralitas pada tataran yang primer.

Kedua, pada aspek penegakan hukum, konsep legal pluralism lebih mengutamakan penggunaan 'hukum negara'. ${ }^{59}$ Di sini, tatanan hukum adat dan hukum transnasional memiliki legitimasi bergantung pada, atau menerima, pengakuan dari badan, teks, atau otoritas tunggal negara yang superordinat. Dengan demikian, legal pluralism tidak memberikan kedudukan yang sejajar; khususnya pada faset penegakan hukum. Dengan demikian, tak salah apabila legal pluralism menitikberatkan pada penyelesaian masalah hukum di peradilan. ${ }^{60}$ Ketiga, legal pluralism memiliki perspektif yang tidak jelas; karena dibangun

\footnotetext{
55 Brian Z. Tamanaha, "The Promise and Conundrums of Pluralist Jurisprudence," The Modern Law Review 82, no. 1 (January 2019): 159-79.

${ }^{56}$ Yashomati Ghosh and Anirban Chakraborty, "Secularism, Multiculturalism and Legal Pluralism: A Comparative Analysis Between the Indian and Western Constitutional Philosophy," Asian Journal of Legal Education 7, no. 1 (January 16, 2020): 73-81.

57 Paul Schiff Berman, The Oxford Handbook of Global Legal Pluralism (Oxford: Oxford University Press, 2020).

58 Bruce Ackerman, “The Emergency Constitution," Journal of Constitutional Law 1, no. Special Edition (2020): 9-63

${ }^{59}$ Sani, "State Law and Legal Pluralism: Towards an Appraisal."

${ }^{60}$ Sophia Sabrow, "Non-Enforcement as a Tool of Mediation in Pluralistic Societies," The Journal of Legal Pluralism and Unofficial Law 52, no. 2 (May 3, 2020): 154-79.
} 
tidak bersandar pada sistem tatanan orientasi bangsa. ${ }^{61}$ Hal tersebut justru menimbulkan kontra ideologi; ${ }^{62}$ yang ditunjukkan adanya 'perlawanan' terhadap hukum negara, hukum transnasional, dan kepentingan pemerintah administrasi maupun adat dalam sistem hukum negara. 'Perlawanan' tersebut ditunjukkan melalui adanya pemaksaan penggabungan norma yang berada dalam hukum adat dan hukum negara; ${ }^{63}$ tanpa memperhatikan aspek orientasi bangsa dan nilai-nilai moralitas dan etika bangsa. Oportunitas konsep legal pluralism tersebut ditunjukkan dengan 'mengambil' norma yang hanya dirasa bermanfaat bagi salah satu pihak, bukan seluruh pihak. ${ }^{64}$

Lalu, apakah strategi pluralisme hukum khas Indonesia dapat membantu eksistensi hukum adat saat ini ? Sangat bisa; mengingat hukum adat akan dapat memenuhi prinsip-prinsip hukum yang baik dan menjaga kewibawaan hukum. ${ }^{65}$ Hanya saja, hal ini dapat dilakukan dengan menggunakan pendekatan multifaset; dikarenakan, apabila hanya sebatas menggunakan pendekatan perspektif hukum dikhawatirkan masyarakat cenderung memilih 'hukum' yang dianggap memberikan suatu jaminan keamanan dan kesejahteraan bagi dirinya; sehingga menciptakan karakter oportunis pada masyarakat adat.

Pluralisme hukum khas Indonesia berperan pula untuk mengidentifikasi dan menguraikan hubungan antara tatanan normatif dengan tatanan lokal sebagai strategi inklusif konseptual sistem hukum negara. Sehingga, hal tersebut mengacu pada kesempatan hukum sebagai salah satu domain dasar praktik keberadaan manusia dalam hal sosial, agama, politik, atau praktik ekonomi; atau beberapa sendi kehidupan manusia yang membutuhkan hukum. Konsep tersebut

${ }^{61}$ Xia Dai, "Studies on the Legal Translation from the Perspective of Legal Pluralism," Theory and Practice in Language Studies 9, no. 8 (2019): 973-77.

62 Toby Osborne, The Routledge Handbook of Translation and Culture, ed. Sue-Ann Harding and Ovidi Carbondell Cortés, The Routledge Handbook of Translation and Culture (New York, NY : Routledge, 2018. | Series: Routledge handbooks in translation and interpreting studies: Routledge, 2018).

${ }^{63}$ Elizabeth Shaw, "Justice Without Moral Responsibility?," Journal of Information Ethics 28, no. 1 (2019).

64 Tusseau, Debating Legal Pluralism and Constitutionalism: New Trajectories for Legal Theory in the Global Age.

${ }^{65}$ Dicky Eko Prasetio, Fradhana Putra Disantara, and Nadia Husna Azzahra, "Peradilan Adat Sendi: Mutiara Di Balik Tirai Hukum Negara," Gresnews.com, 2020. 
mencerminkan bahwa hukum berada pada tingkat abstraksi daripada hukum dogmatis.

Konsep pluralisme hukum khas Indonesia mendorong sistem hukum hadir di setiap bidang sosial semi-otonom; karena setiap masyarakat memiliki aktivitasi pada berbagai bidang. Konsep tersebut merupakan fitur universal dari organisasi sosial. Hal ini sejalan dengan pandangan, yang menyatakan bahwa perspektif fungsional hukum berada dalam relasi sosial sebagai bentuk kontrol sosial; sehingga hukum dapat ditemukan dalam hubungan sosial Dengan cara ini, pluralisme hukum khas Indonesia menentang asumsi monopoli negara membuat, mengelola, memberlakukan, dan memberikan sanksi terhadap hukum.

Pluralisme hukum khas Indonesia menganggap keadilan sosial sebagai hal terpenting bagi validitas hukum; sekaligus refleksi dari sila ke-5 Pancasila. Pluralisme hukum khas Indonesia dikaji secara teoritis melalui dua pendekatan; yaitu relasionalisme dan konsekuensialisme. Pada aspek relasionalisme, konsep tersebut berfokus pada sifat tatanan hukum yang majemuk yang pada akhirnya menimbulkan 'kerja sama' di antara ketiga sistem tersebut; dan menimbulkan pengaruhnya terhadap satu sama lain pula. Pada faset konsekuensialisme, konsep Indonesian legal pluralism dapat menghasilkan pemberdayaan; yang menawarkan ruang lingkup pendidikan hukum bagi masyarakat melalui berbagai forum hukum. Kemudian, konsep di atas melahirkan ketersediaan normatif dan pilihan kelembagaan dan potensi inovasi prosedural dan kelembagaan hukum; selagi masyarakat mampu menyesuaikan diri dengan lebih baik untuk mempertahankan hak mereka.

Melalui konsep tersebut, kajian tentang penyusunan peraturan perundangundangan diharapkan dapat lebih memperhatikan pada aspek cara penyelenggaraan pemerintahan, keadaan sumber daya alam dan manusia, problematika keadilan, dan masih banyak lagi persoalan. Perspektif pluralisme hukum akan menawarkan cara yang bermanfaat untuk memahami dinamika bagaimana hukum dipertahankan dan dimodifikasi dalam rantai interaksi, pengaturan, dan konteks. Apa yang terjadi dalam satu konteks, misalnya dalam ruang dan kerangka pengadilan, dapat mempengaruhi konteks lain. Dengan demikian, konsep pluralisme hukum khas 
Indonesia dapat mendorong penyusunan peraturan perundang-undangan memahami secara spesifik dan konteks pada tatanan normatif untuk ditafsirkan dan dipraktikkan; perihal akomodasi hak-hak konstitusional dari warga negara.

Konsep pluralisme hukum khas Indonesia di atas bukan tanpa dasar; mengingat Pasal 18B Ayat (2), Pasal 28I Ayat (3), serta Pasal 32 Ayat (1) dan (2) UUD NRI mengamanatkan kepada Negara untuk memelihara, memajukan, menjamin, mengakui, dan menghormati kesatuan masyarakat adat sebagai kekayaan budaya nasional beserta segala hak-haknya di tengah peradaban dunia. Bukan hanya itu, tujuan negara yang terdapat dalam alinea keempat Pembukaan UUD NRI 1945 khususnya pada frasa " ... memajukan kesejahteraan umum ..." melahirkan konsekuensi moral kepada negara untuk mewujudkan keadilan sosial bagi seluruh rakyat Indonesia; ${ }^{66}$ tak terkecuali masyarakat adat yang telah mengikatkan diri menjadi bagian ciri khas bangsa Indonesia. Dengan demikian, sangat wajar apabila UUD NRI 1945 dan tujuan negara yang berada dalam alinea IV Pembukaan UUD NRI 1945 menjadi margin of appreciation dalam menanggapi hukum dari luar; dengan mensejajarkan kedudukan hukum adat dengan hukum nasional. ${ }^{67}$

Pluralisme hukum khas Indonesia dilakukan melalui reframming, revitalisasi, dan reproduksi atas hukum-hukum adat yang berlaku untuk menyesuaikan dengan kerangka hukum nasional dan hukum internasional. Hal tersebut sejalan dengan asas cessante local ratione legisl cessat ipsa lex. Oleh karena itu, tidak ada lagi mapping of legal universe yang menarik garis batas yang tegas untuk membedakan antara hukum nasional, hukum adat, dan hukum internasional. Bahkan, ketiganya bersatu padu secara bersama-sama untuk menyelesaikan permasalahan melalui praktik hukum. Dengan demikian, corak plurlisme hukum Indonesia memperhatikan segala pihak yang menyebabkan hukum bergerak sebagai instrumen kontekstualisasi sejarah bangsa; mengingat

\footnotetext{
66 Fradhana Putra Disantara, "Pancasila Juga Volksgeist, Tanya Kenapa ?," in Filsafat Hukum Pancasila (Suatu Kajian Filsafat, Hukum, Dan Politik), ed. Irfa Ronaboyd and Fradhana Putra Disantara (Jakarta Selatan: Kreasi Cendekia Pustaka, 2020), 63-68.

67 Dicky Eko Prasetio, Fradhana Putra Disantara, and Nadia Husna Azzahra, "Menanti Legalisasi Desa Adat Sendi, Sampai Kapan?," mediajatim.com, 2020.
} 
sistem hukum berasal dari tataran yang berbeda-beda dan kemudian saling bersentuhan, berkontestasi, reproduksi, dan mengadopsi satu sama lain secara luas. $^{68}$

Ketiga sistem hukum yang berjalan secara beriringan tersebut diharapkan dapat memenuhi tiga aspek tanggung jawab negara. ${ }^{69}$ Pertama, to respect. Konsep tersebut mendorong pemerintah untuk memberikan legitimasi bagi seluruh pihak khususnya kepada masyarakat adat-; baik secara administrasi maupun nonadministrasi. Rekognisi dari pemerintah tersebut mengakomodasi aspek teknologi serta pengetahuan pula. Sehingga, melalui perkembangan teknologi; pemerintah dapat melakukan pendataan administrasi dan data pribadi bagi seluruh masyarakat. Makna rekognisi di atas adalah tindakan solutif dari pemerintah tidak boleh mendiskriminasi individu atau kelompok tertentu. Prinsip non diskriminasi tersebut sesuai dengan konsepsi Marianne O. Nielsen; ${ }^{70}$ yang menyatakan bahwa seluruh norma hukum yang berlaku di suatu negara harus memberikan rasa keadilan melalui aparaturnya.

Kedua, to protect. Peneguhan pemerintah terhadap hak-hak konstitusional masyarakat dapat dilakukan dengan memberikan seluruh lapisan masyarakat kesempatan yang sama; untuk pro-aktif dalam berbagai pembangunan infrastruktur maupun sumber daya manusia. Di sisi lain, perlindungan yang diberikan pemerintah dapat diaktualisasikan dengan melaksanakan pemberdayaan bagi seluruh lapisan masyarakat agar dapat hidup tumbuh dan berkembang sesuai dengan nilai-nilai moral yang hidup dilingkungannya. Aksi afirmasi tersebut sejalan dengan pandangan Peter G. Staubach; ${ }^{71}$ yang menyatakan bahwa hukum patut meninjau aspek pluralistik dimasyarakat sebagai konsekuensi asas actus legis nemini est damnosus. Ketiga, to fulfill. Norma-norma yang berada dalam peraturan

\footnotetext{
${ }^{68}$ Berman, The Oxford Handbook of Global Legal Pluralism.

69 Fradhana Putra Disantara, "Tanggung Jawab Negara Dalam Masa Pandemi Covid-19," Jurnal Cendekia Hukum 6, no. 1 (2020): 48-20.

70 Marianne O. Nielsen and Karen Jarratt-Snider, eds., Traditional, National, and International Law and Indigenous Communities (Arizona: University of Arizona Press, 2020).

${ }^{71}$ Staubach, The Rule of Unwritten International Law: Customary Law, General Principles, and World Order.
} 
perundang-undangan yang menyasar tentang masyarakat adat; harus mengakomodasi hak-hak konstitusional masyarakat adat.

Strategi pluralisme hukum khas Indonesia dapat dilakukan secara kontinu dengan menjalankan empat aspek. Pertama, hukum adat harus beradaptasi dengan kebutuhan situasional yang berasal dari luar. Hal tersebut berfungsi agar hukum adat dapat menyesuaikan dengan lingkungan sesuai kebutuhan daripada hukum adat itu sendiri. Di sisi lain, hukum adat memiliki prinsip dinamis; yaitu hukum adat dapat mengikuti dinamika perkembangan kehidupan sosial, mengingat hukum adat berangkat dari konsensus facit legem dan konsensus ad idem. ${ }^{72}$ Kedua, hukum adat harus selalu menjaga tujuan utamanya. Maknanya, ciri khas yang bersandar pada hukum adat wajib dipertahankan dan dilestarikan. Ketiga, adanya integrasi dengan hukum-hukum yang lain untuk mengatur hubungan bagian-bagian yang menjadi komponen hukum adat. Keempat, hukum adat harus melengkapi, memelihara, dan memperbaharui motivasi masyarakat adat dan pola-pola budayanya; guna menciptakan dan mempertahankan motivasi untuk menjadikan hukum adat sebagai orientasi hukum bersama.

Dengan demikian, pluralisme hukum khas Indonesia menjadikan hukum negara, hukum transnasional, dan hukum adat berjalan secara bersama-sama dan berkedudukan sejajar; dengan didasarkan atas UUD NRI 1945 sebagai arah tujuan hidup bangsa sekaligus peletak kehidupan bangsa yang berinteraksi secara konstan untuk menghadapi berbagai permasalahan hukum. Di sisi lain, konsep pluralism hukum khas Indonesia berdiri atas prinsip propter veritatem et justitiam; mengingat seluruh sistem hukum yang berlaku di Indonesia memiliki orientasi yang baik untuk mencapai perlindungan yang holistik, ${ }^{73}$ sejalan dengan asas lex est tutissima cassis sub clypeo legisl nemo decipitur.

72 Dominikus Rato et al., Kearifan Lokal Masyarakat Hukum Adat Dalam Mewujudkan Kedaulatan Pangan Ditengah Pandemi Covid 19, ed. Ning Adiasih, C. Woro Murdiati R, and Rina Yulianti (Jakarta: Lembaga Studi Hukum Indonesia (LSHI), 2020).

${ }^{73}$ Fradhana Putra Disantara, “Aspek Imunitas Dalam Penanganan Corona Virus Disease 2019," Istinbath : Jurnal Hukum 17, no. 1 (2020): 65-82. 


\section{Indonesian Legal Pluralism sebagai Strategi untuk Mengintegrasikan Peradilan Adat dalam Sistem Hukum Nasional}

Kebaharuan konsep pluralisme hukum yakni Indonesia legal pluralism akan memberikan dorongan adanya intergrasi atas antara satu instrumen hukum dengan yang lainnya, tak terkecual peradilan adat. Peradilan adat menjadi instrumen ciri khas hukum adat; karena menjadi aspek praktik dari norma-norma hukum adat yang ada di masyarakat. ${ }^{74}$ Peradilan adat hadir bersamaan dengan tumbuh dan berkembangnya hukum adat di suatu daerah, dan sebagai mekanisme formil untuk menegakkan hukum adat yang lebih bersifat materiil. ${ }^{75}$

Peradilan adat memiliki otonomi yudisial; ${ }^{76}$ artinya, peradilan adat dapat memeriksa dan memutus perkara adat yang ada dalam masyarakat. Meskipun demikian, peradilan adat tetap merupakan satu rangkaian dengan sistem peradilan nasional. ${ }^{77}$ Sejalan dengan asas lex quadam, rationalis ordinatio ad bonum commune, ab eo qui cura communitatis habet promulgata (hukum itu adalah pemikiran bersama masyarakat dan harus dilestarikan untuk kepentingan masyarakat); masyarakat adat cenderung melakukan transplantasi konstitusi yang melahirkan peradilan adat sebagai salah satu instrumen hukum. Menurut Paul Kuruk, $^{78}$ peradilan adat memiliki beberapa kelebihan; diantaranya: Pertama, fleksibilitas dan relevantif. Peradilan adat berkembang seiring berkembangnya komunitas masyarakat adat; dan karena itu peradilan adat relevan dengan perubahan keadaan di komunitas. Oleh karenanya, hukum adat dapat menjadi lebih modern daripada hukum tertulis, terutama jika dianggap ada hukum yang kadaluwarsa dan kuno dalam kitab undang-undang.

Kedua, adanya 'rasa saling memiliki'. Peradilan adat memberi masyarakat rasa memiliki karena sifat partisipatifnya. Keluarga terdakwa dan korban

\footnotetext{
${ }^{74}$ Hilman Syahrial Haq, Pengantar Hukum Adat (Klaten: Lakeisha, 2020).

75 Jaja Ahmad Jayus, Hukum Adat: Teori, Sejarah, Pengakuan Negara, Dan Yuriprudensi (Jakarta Selatan: Rajawali Press, 2020).

${ }^{76}$ Gerlov van Engelenhoven, "From Indigenous Customary Law to Diasporic Cultural Heritage: Reappropriations of Adat Throughout the History of Moluccan Postcolonial Migration," International Journal for the Semiotics of Law, 2020, 1-27.

${ }_{77}$ Mansur, Sulaiman, and Ali, “Adat Court in Aceh, Indonesia: A Review of Law."

78 Kuruk, Traditional Knowledge, Genetic Resources, Customary Law and Intellectual Property: A Global Primer.
} 
berpartisipasi dalam proses tersebut. Mereka tahu apa yang diharapkan dan bagaimana bertindak sendiri -aturan dan prosedur diketahui- karena didasarkan pada hukum yang mereka ketahui, dan oleh karena itu proses peradilan adat dipahami oleh semua anggota masyarakat adat. Ketiga, kesederhanaan dan keakraban. Bahasa yang digunakan adalah bahasa daerah para pihak yang berkepentingan; oleh karenanya meningkatnya keakraban antara seluruh pihak yang berperkara. Keempat, peradilan adat didasarkan pada mediasi dan mendukung keputusan yang restoratif. Hal ini sesuai dengan kebutuhan masyarakat dan cenderung membangun kembali hubungan masyarakat dibandingkan dengan sistem formal yang berbasis sanksi berupa denda, kurungan maupun penjara. Kelima, peradilan adat mudah untuk diakses, murah dan cepat. Di sisi lain, orangorang dapat saling memaafkan dan hidup bersama setelah persidangan selesai.

Dengan demikian, berbagai kelebihan peradilan adat di atas patut untuk memberikan elemen baru pada sistem hukum nasional. Integrasi peradilan adat terhadap peradilan dan sistem hukum nasional sejatinya perlu digalakkan. Dorongan tersebut setidaknya dilandasi oleh dua argumentasi. Pertama, terkait dengan eksistensi peradilan adat itu sendiri. Apabila tidak ada upaya integrasi terkait sistem peradilan adat dengan sistem peradilan nasional, maka ke depannya eksistensi peradilan adat dapat terganggu; bahkan menjadi hilang karena tidak memiliki legitimasi setara dengan peradilan nasional dan hukum negara. Kedua, integrasi antara peradilan adat dengan peradilan nasional sejatinya bertujuan untuk mengkolaborasikan aparatur penegak hukum serta sistem peradilan baik yang terdapat dalam peradilan adat maupun yang terdapat dalam sistem peradilan nasional.

Dengan demikian, praktik peradilan adat sebagai peculiar of social life menjadi keniscayaan di tengah modernisasi hukum. ${ }^{79}$ Hal tersebut dikarenakan hukum adat merupakan the margin of appreciation atas segala aspek yang disebabkan oleh modernisasi hukum. ${ }^{80}$ Namun, masyarakat adat selalu

\footnotetext{
${ }^{79}$ Kuruk.

${ }^{80}$ Žemaitèlytė-Ivanavičè, "The Confrontation of Education and Customary Law At School: The Case Of Roma."
} 
menitikberatkan pada proses peradilan adat dan sebisa mungkin meminimalisasi 'kontak' dengan aparatur penegak hukum maupun peradilan nasional. ${ }^{81}$ Hanya saja, apabila fenomena di atas dipertahankan; dapat pula menimbulkan permasalahan kelak di kemudian hari. Misalnya, ketika terjadi kasus pencurian di masyarakat adat ; dan telah diputuskan berdasarkan pada aturan dan mekanisme adat. Akan tetapi, pihak aparatur hukum negara ingin melakukan investigasi dan berupaya melanjutkan permasalahan tersebut di jalur hukum formal negara. Tentu, fenomena tersebut memungkinkan terjadinya benturan antara hukum adat dan hukum negara.

Perihal tersebut sebagaimana yang digambarkan oleh Ter Haar, bahwa meskipun hukum itu merupakan hukum keputusan (judge made law), namun ketika terjadi perbedaan proses dan hasil putusan antara hukum negara dengan hukum adat yang berada di masyarakat; maka hukum negara menjadi lebih superior dibandingkan dengan hukum adat. ${ }^{82}$ Dalam hal ini, ketika hukum adat berbenturan dengan hukum nasional maka hukum nasional layaknya menjadi harimau yang dapat menerkam kambing yang diibaratkan sebagai hukum adat. ${ }^{83}$ Oleh karena itu, berdasarkan dua argumentasi tersebut; maka integrasi antara peradilan adat dengan sistem peradilan nasional termasuk aparatur hukumnya penting untuk dilakukan melalui pendekatan pluralisme hukum khas Indonesia yang berorientasi pada kearifan lokal; yang bertujuan pula untuk meneguhkan ketahanan hukum adat dalam masyarakat adat.

Strategi pluralisme hukum khas Indonesia berperan sebagai sarana integrasi antara hukum adat bersama aparaturnya dengan sistem peradilan nasional dan aparatur hukum nasional. Elemen religi, moral, sosial, lokal sebagai refleksi batang tubuh pembukaan UUD NRI 1945 menjadi komponen fundamen; untuk menjalin interaksi diantara norma hukum adat dan hukum nasional. Integrasi antara norma hukum adat dan hukum negara diharapkan menghasilkan tujuan hukum berupa

81 Dicky Eko Prasetio, Fradhana Putra Disantara, and Nadia Husna Azzahra, "Kitab Kutaramanawa Dharmasastra Dan Supremasi Konstitusi Jaman Majapahit," beritajatim.com, 2020.

82 Dirk ter Haar, Asas-Asas Dan Susunan Hukum, ed. Soebakti Pesponoto (Jakarta: Balai Pustaka, 2017).

${ }^{83}$ Lucy, "Access to Justice and the Rule of Law." 
manifestasi nilai-nilai moral dalam kehidupan sehari. ${ }^{84}$ Jika dikaitkan dengan strategi pluralisme hukum khas Indonesia, maka yang lebih dioptimalkan bukan hanya integrasi antara norma adat dan norma hukum nasional semata; melainkan termasuk juga integrasi antara aparatur hukum adat dengan aparatur hukum nasional. Dengan demikian, konsep pluralisme hukum khas Indonesia diharapkan dapat menjaga relevansi antara nilai-nilai moral masyarakat terhadap era modernisasi hukum; yang dicirikan dengan semakin besarnya dominasi serta peran hukum negara.

Di sisi lain, konsep Indonesian legal pluralism berorientasi pada kemanusiaan yang adil dan beradab; serta keadilan sosial bagi seluruh rakyat Indonesia. Perihal tersebut ditunjukkan dengan mengoptimalkan peran penyelesaian sengketa di luar pengadilan (mediasi). Penyelesaian sengketa di luar pengadilan akan menjadi lebih efektif apabila didukung oleh suatu sistem serta aparatur sosial-kemasyarakatan yang bersifat lokal; sebagaimana yang terjadi pula pada masyarakat adat dengan peradilan adatnya. Pada masyarakat adat, praktik peradilan adat dapat tidak dilaksanakan dengan mengedepankan rule and procedures. Hanya saja, peradilan adat menggunakan pendekatan yang bersifat preventif, restitutif, serta edukatif. Dengan demikian, meski tetap melaksanakan ketentuan formal -bersandar pada hukum adat- dalam peradilan adat; namun aparatur hukum adat tidak menganggap rule and procedures sebagai ketaatan terhadap hukum.

Aparatur hukum adat justru bertindak sebaliknya; bahwa pendekatan yang bersifat humanis harus diutamakan dengan mengedepankan aspek keadilan substansial yang dibingkai dalam prosedur formal khas peradilan adat. Oleh karena itu, aparatur hukum adat melihat rule and procedures sebagai 'bingkai' yang harus dilaksanakan untuk menjaga nilai-nilai moral di masyarakat; bukan sebagai beban yang harus dijalankan hingga menyebabkan terdelegitimasinya aspek kemanusiaan serta keadilan substansial pada masyarakat adat. Praktik berhukum khas

\footnotetext{
${ }^{84}$ Cadey Korson, Sybille Poaouteta, and Gerard Prinsen, "Triangular Negotiations of Island Sovereignty: Indigenous and Customary Authorities - Metropolitan States - Local Metropolitan Authorities," Island Studies Journal 15, no. 1 (2020): 67-88.
} 
masyarakat adat tersebut sejatinya menjadi salah satu faktor untuk merekonstruksi praktik peradilan adat dengan pendekatan pluralisme hukum khas Indonesia. Pendekatan Indonesian legal pluralism dilakukan agar keberadaan peradilan adat didudukkan pula sebagai tempat masyarakat adat untuk mencari keadilan. Perlu dipahami, masyarakat adat memang menggunakan sarana peradilan adat; hanya peradilan adat tersebut dilaksanakan dengan norma, aparatur hukum, serta prosedur yang khas masyarakat adat.

Sehingga, masyarakat adat tidak terkesan asing dengan praktik peradilan yang dijalankan. Kedekatan masyarakat adat dengan berbagai instrumen hukum adat membuat masyarakat adat menjadi lebih taat serta menghormati setiap proses pembinaan hingga penegakan hukum di masyarakat adat. Oleh karena itu, agar proses pembinaan hukum pada masyarakat adat dapat berjalan secara optimal serta memiliki validitas yang tidak berbeda jauh dengan hukum negara; maka perlu dilakukan suatu pendekatan pluralisme hukum khas Indonesia serta integrasi peradilan adat dengan sistem peradilan nasional. Integrasi antara hukum adat termasuk aparaturnya dengan sistem peradilan nasional serta aparatur nasional dapat dilakukan dalam anah pembinaan hukum. Strategi pluralisme hukum khas Indonesia diformulasikan dalam bentuk sosialisasi oleh tetua adat bersama aparatur hukum negara. Teknisnya, manakala pemuda adat berkumpul di suatu tempat, tetua adat bersama aparatur hukum negara memberikan berbagai petuah kepada generasi muda. Hal tersebut perlu dilakukan untuk menjamin sinkronisasi nilai esensial antara hukum adat dan hukum nasional yang sejalan dengan asas lex ratio summa insita in natura, quae juber ea, quae facienda sunt, prohibitque contrary. ${ }^{85}$

Strategi tersebut dapat dilakukan secara rutin oleh aparatur hukum negara sebagai saluran sosialisasi hukum negara terhadap kearifan lokal masyarakat. Di sisi lain, perlu dilakukan secara rutin sekaligus sebagai bentuk upaya aparatur hukum negara untuk melakukan 'jemput bola' terhadap kearifan lokal masyarakat dengan praktik hukum adatnya. Strategi pluralisme hukum khas Indonesia mendorong adanya pembangunan hukum adat melalui berbagai aspek; diantaranya:

\footnotetext{
85 Tusseau, Debating Legal Pluralism and Constitutionalism: New Trajectories for Legal Theory in the Global Age.
} 
sumber daya manusia masyarakat adat, keahlian masyarakat adat, sumber daya alam yang dimiliki masyarakat adat, kemampuan kewirausahaan masyarakat adat untuk meningkatkan kemampuan finansial, dan lain sebagainya. Berbagai elemen di atas, di akomodasi oleh peradilan adat; apabila terdapat suatu problematika hukum yang terjadi di lingkungan masyarakat.

Mengapa demikian? Peradilan adat hidup berdampingan dengan berbagai aktivitas masyarakat adat pula; sehingga aspek moralitas, budaya, dan filosofi dari tindakan masyarakat dapat dimaklumi oleh peradilan adat. Elemen moralitas, budaya, dan filosofis inilah yang menjadi ciri khas integrasi khas pluraslime hukum di Indonesia. Bukan hanya itu, melalui strategi pluralisme hukum khas Indonesia; peradilan adat dapat diberikan power legitimation oleh pemerintah. Hal tersebut dikarenakan peran pemerintah memiliki kewajiban untuk menjaga kultur budaya bangsa dari berbagai ancaman pendatang baru. Power legitimation tersebut dapat diberikan oleh pemerintah berupa peraturan perundang-undangan tentang Masyarakat Adat; yang hingga kini masih menjadi RUU, dan tetap belum dilakukan pengesahan terhadapnya.

Oleh karena itu, peradilan adat adalah sistem hukum dominan yang memberikan keadilan di tingkat akar rumput di dalam suatu negara. Pluralisme hukum khas Indonesia akan mengkontaminasi keterkaitan antara pengadilan hukum, pengadilan agama, dan forum penyelesaian sengketa non-negara. Dengan demikian, melalui konstitusi kita; hendaknya pemerintah tidak akan menghalangi putusan pengadilan adat atas perselisihan yang berkaitan dengan hukum pribadi dan keluarga sesuai dengan hukum adat, dengan persetujuan dari para pihak yang berselisih. Di sisi lain, sebagai refleksi tujuan hidup bangsa; negara dapat menetapkan atau memberikan pengakuan resmi kepada pengadilan adat yang berfungsi melahirkan sinar-sinar konstitusi.

\section{Penutup}

Fenomena modernisasi hukum sebagai implikasi dari era globalisasi mewujudkan karakter hukum yang legal-formal-prosedural serta berdimensi pada aturan tertulis; yang menyebabkan adanya dikotomi antara hukum nasional dan hukum adat. Bukan hanya itu, fenomena modernisasi hukum melahirkan sistem 
hukum baru, yaitu hukum transnasional sebagai konsekuensi atas terjadinya adaptasi hukum nasional serta pemenuhan kepentingan akan kerjasama antar bangsa. Dengan demikian, diperlukan suatu konsep kebaharuan pluralism hukum, yaitu Indonesian legal pluralism atau pluralism hukum khas Indonesia. Konsepsi tersebut merupakan pengembangan atas konsep legal pluralism yang dikemukaka oleh Werner Menski. The concept of Indonesian legal pluralism menambahkan berbagai konsep yang bersandar pada aspek transnasional; sehingga natural law, international law, positive law, dan social-legal dapat diberlakukan secara bersama sama yang didasarkan atas Undang Undang Dasar Negara Republik Indonesia tahun 1945 (UUD NRI 1945) dan visi misi dari Negara Kesaturan Republik Indonesia, khususnya Alinea keempat IV. Konsep di atas dapat dijadikan sebagai strategi untuk mengintegrasikan peradilan adat dalam sistem hukum nasional. Strategi tersebut dapat dilakukan dalam ranah pembinaan hukum; yang dilakukan oleh tetua adat bersama aparatur hukum nasional dengan memberikan petuah kepada generasi muda. Hal tersebut perlu dilakukan untuk menjamin sinkronisasi nilai esensial antara hukum adat dan hukum nasional.

\section{DAFTAR PUSTAKA}

\section{Buku}

Berman, Paul Schiff. The Oxford Handbook of Global Legal Pluralism. Oxford: Oxford University Press, 2020.

Disantara, Fradhana Putra. "Pancasila Juga Volksgeist, Tanya Kenapa?" In Filsafat Hukum Pancasila (Suatu Kajian Filsafat, Hukum, Dan Politik), edited by Irfa Ronaboyd and Fradhana Putra Disantara, 63-68. Jakarta Selatan: Kreasi Cendekia Pustaka, 2020.

Haar, Dirk ter. Asas-Asas Dan Susunan Hukum. Edited by Soebakti Pesponoto. Jakarta: Balai Pustaka, 2017.

Haq, Hilman Syahrial. Pengantar Hukum Adat. Klaten: Lakeisha, 2020.

Insole, Christopher J. Kant and the Divine: From Contemplation to the Moral Law. New York: Oxford University Press, 2020.

Jany, Janos. Legal Traditions in Asia: History, Concepts and Laws. Cham: Springer Nature, 2020.

Jayus, Jaja Ahmad. Hukum Adat: Teori, Sejarah, Pengakuan Negara, Dan Yuriprudensi. Jakarta Selatan: Rajawali Press, 2020.

Kuruk, Paul. Traditional Knowledge, Genetic Resources, Customary Law and Intellectual Property: A Global Primer. Cheltenham: Edward Elgar 
Publishing, 2020.

Marzuki, Peter Mahmud. Penelitiam Hukum. 13th ed. Jakarta: Kencana, 2017.

Menski, Werner F. Comparative Law in a Global Context: The Legal Systems of Asia and Africa. Comparative Law in a Global Context: The Legal Systems of Asia and Africa, Second Edition. 2nd ed. Cambridge: Cambridge University Press, 2006.

Nielsen, Marianne O., and Karen Jarratt-Snider, eds. Traditional, National, and International Law and Indigenous Communities. Arizona: University of Arizona Press, 2020.

Osborne, Toby. The Routledge Handbook of Translation and Culture. Edited by Sue-Ann Harding and Ovidi Carbondell Cortés. The Routledge Handbook of Translation and Culture. New York, NY: Routledge, 2018. | Series: Routledge handbooks in translation and interpreting studies: Routledge, 2018.

Rahardjo, Satjipto. Membedah Hukum Progresif. Jakarta: Penerbit Buku Kompas, 2006.

Rato, Dominikus, Laksanto Utomo, I Gusti Agung Mas Rwa Jayantiari, Simona Bustami, Aartje Tehupeiory, Marlisa Ayu Trisia, Abdul Rahman Nur, et al. Kearifan Lokal Masyarakat Hukum Adat Dalam Mewujudkan Kedaulatan Pangan Ditengah Pandemi Covid 19. Edited by Ning Adiasih, C. Woro Murdiati R, and Rina Yulianti. Jakarta: Lembaga Studi Hukum Indonesia (LSHI), 2020.

Samara, Angeliki. Beyond the Responsibility to Protect in International Law: An Ethics of Irresponsibility. New York: Routledge, 2020.

Schulz, Jennifer L. Mediation \& Popular Culture. New York: Routledge, 2020.

Sinai, Yuval, and Benjamin Shmueli. Maimonides and Contemporary Tort Theory: Law, Religion, Economics, and Morality. Cambridge: Cambridge University Press, 2020.

Staubach, Peter G. The Rule of Unwritten International Law: Customary Law, General Principles, and World Order. Milton Park: Taylor \& Francis, 2020.

Tusseau, Guillaume, ed. Debating Legal Pluralism and Constitutionalism: New Trajectories for Legal Theory in the Global Age. New York: Springer Nature, 2020.

Wulansari, Rr Catharina Dewi. Hukum Adat Indonesia - Suatu Pengantar. 4th ed. Bandung: PT Refika Aditama, 2016.

\section{Jurnal Artikel}

Abotsi, E. Kofi. "Customary Law and the Rule of Law." Arizona Journalof International \& Comparative Law 37, no. 2 (2020): 137-66.

Ackerman, Bruce. "The Emergency Constitution." Journal of Constitutional Law 1, no. Special Edition (2020): 9-63.

Aspan, Zulkifli, and Wiwin Suwandi. "Menjerat Kader, Melepas Partai Politik; Pertanggungjawaban Pidana Partai Politik Dalam Kasus Tindak Pidana Korupsi." Al-Adalah: Jurnal Hukum Dan Politik Islam 5, no. 1 (April 30, 2020): 57-78.

Aswar, Hasbi, Danial Bin Mohd. Yusof, and Rohana Binti Abdul Hamid. 
"Conflict Between Hizb Ut-Tahrir And Islamic Civil Society In Indonesia:A Countermovement Approach.” Al-Adalah: Jurnal Hukum Dan Politik Islam 5, no. 2 (July 30, 2020): 171-91.

Bittar, Eduardo C. B. "Semiotics of Law, Juridicity and Legal System: Some Observations and Clarifications of a Theoretical Concept." International Journal for the Semiotics of Law 1, no. 1 (November 11, 2020): 1-24.

Bose, Neilesh, and Victor V. Ramraj. "Lex Mercatoria, Legal Pluralism, and the Modern State through the Lens of the East India Company, 1600-1757." Comparative Studies of South Asia, Africa and the Middle East 40, no. 2 (August 1, 2020): 277-90.

Britton-Purdy, Jedediah, David Singh Grewal, Amy Kapczynski, and K. Sabeel Rahman. "Building a Law-and-Political-Economy Framework: Beyond the Twentieth-Century Synthesis." Yale Law Journal 129, no. 6 (2020): 17861832.

Corrin, Jennifer. "Plurality and Punishment: Competition Between State and Customary Authorities in Solomon Islands." The Journal of Legal Pluralism and Unofficial Law 51, no. 1 (January 2, 2019): 29-47.

Cortés-Nieto, Johanna Del Pilar. "Transnational Law and Development as a Means to Reshape States and Rights." Journal of Law and Society 47, no. 4 (November 10, 2020): 694-701.

Dai, Xia. "Studies on the Legal Translation from the Perspective of Legal Pluralism." Theory and Practice in Language Studies 9, no. 8 (2019): 97377.

Disantara, Fradhana Putra. "Aspek Imunitas Dalam Penanganan Corona Virus Disease 2019." Istinbath : Jurnal Hukum 17, no. 1 (2020): 65-82.

Disantara, Fradhana Putra. "Tanggung Jawab Negara Dalam Masa Pandemi Covid-19.” Jurnal Cendekia Hukum 6, no. 1 (2020): 48-20.

Disantara, Fradhana Putra. "The Large Scale Social Restrictions Policy For Handling The COVID-19 Pandemic." Jurnal Pembaharuan Hukum 7, no. 2 (2020): 128-41.

Disantara, Fradhana Putra. "The Legitimacy of Circular Letter in Handling COVID-19 Pandemic." Rechtsidee 6, no. 2 (2020): 1-10.

Engelenhoven, Gerlov van. "From Indigenous Customary Law to Diasporic Cultural Heritage: Reappropriations of Adat Throughout the History of Moluccan Postcolonial Migration." International Journal for the Semiotics of Law, 2020, 1-27.

Gharios, Georges. "Legal Pluralism and Un-Official Law in Lebanon: Evolution and Sustainable Development of Water." Water Policy 22, no. 3 (June 1, 2020): 348-64.

Ghosh, Yashomati, and Anirban Chakraborty. "Secularism, Multiculturalism and Legal Pluralism: A Comparative Analysis Between the Indian and Western Constitutional Philosophy." Asian Journal of Legal Education 7, no. 1 (January 16, 2020): 73-81.

Ginsburg, Tom. "Authoritarian International Law?" American Journal of International Law 114, no. 2 (April 3, 2020): 221-60.

Jentoft, Svein, and Maarten Bavinck. "Reconciling Human Rights and Customary 
Law: Legal Pluralism in The Governance of Small-Scale Fisheries." The Journal of Legal Pluralism and Unofficial Law 51, no. 3 (September 2, 2019): 271-91.

Johnson, Nevin. "Legality's Law's Empire.” Law and Philosophy 39, no. 3 (June 23, 2020): 325-49.

Kahraman, Filiz, Nikhil Kalyanpur, and Abraham L. Newman. "Domestic Courts, Transnational Law, and International Order." European Journal of International Relations 26, no. 1_suppl (September 28, 2020): 184-208.

Korson, Cadey, Sybille Poaouteta, and Gerard Prinsen. "Triangular Negotiations of Island Sovereignty: Indigenous and Customary Authorities - Metropolitan States - Local Metropolitan Authorities." Island Studies Journal 15, no. 1 (2020): 67-88.

Ledvinka, Tomáš. "The Disenchantment of the Lore of Law: Jacob Grimm's Legal Anthropology Before Anthropology." The Journal of Legal Pluralism and Unofficial Law 52, no. 2 (May 3, 2020): 203-26.

Lemos, Miguel De. "Legal Pluralism And International Development: Introductory Notes On The Dialogue Between The Two Concepts." Humanities And Rights | Global Network Journal 2, no. 1 (June 24, 2020): 190-233.

Lubaale, Emma Charlene. "Legal Pluralism As a Lens Through Which to Understand The Role and Place of Tjms in International Criminal Justice." The Journal of Legal Pluralism and Unofficial Law 52, no. 2 (May 3, 2020): 180-202.

Lucy, William. "Access to Justice and the Rule of Law." Oxford Journal of Legal Studies 40, no. 2 (June 1, 2020): 377-402.

Mansur, Teuku Muttaqin, Sulaiman Sulaiman, and Hasbi Ali. "Adat Court in Aceh, Indonesia: A Review of Law." Jurnal Ilmiah Peuradeun 8, no. 2 (May 30, 2020): 423.

Meerssche, Dimitri Van Den, and Geoff Gordon. "A New Normative Architecture' - Risk and Resilience as Routines of Un-Governance." Transnational Legal Theory 11, no. 3 (July 2, 2020): 267-99.

Mulyono, Mulyono, Dewi Setyowati, and Kamarudin Kamarudin. “Tanggung Jawab Hukum Atas Pasien Gangguan Jiwa Yang Melarikan Diri Dari Ruang Rawat Inap Rumah Sakit.” Al-Adalah: Jurnal Hukum Dan Politik Islam 3, no. 1 (July 3, 2019): 56-65.

Naso, Pedro, Erwin Bulte, and Tim Swanson. "Legal Pluralism in Post-Conflict Sierra Leone." European Journal of Political Economy 61 (January 2020): $1-21$.

Pareke, JT, and Fahmi Arisandi. "Pengakuan Masyarakat Hukum Adat Dan Perlindungan Wilayah Adat Di Kabupaten Rejang Lebong." Bina Hukum Lingkungan 4, no. 2 (April 26, 2020): 313.

Pratiwi, Putri Fransiska Purnama, Suprayitno, and Triyani. "Existence of Customary Law through Comparative Education between Dayak Ngaju Customary Law and National Law." Budapest International Research and Critics Institute (BIRCI-Journal) : Humanities 3, no. 2 (2020).

Sabrow, Sophia. "Non-Enforcement as a Tool of Mediation in Pluralistic 
Societies." The Journal of Legal Pluralism and Unofficial Law 52, no. 2 (May 3, 2020): 154-79.

Sani, Hanisah Binte Abdullah. "State Law and Legal Pluralism: Towards an Appraisal." The Journal of Legal Pluralism and Unofficial Law 52, no. 1 (January 2, 2020): 82-109.

Shaw, Elizabeth. "Justice Without Moral Responsibility?" Journal of Information Ethics 28, no. 1 (2019).

Shodiq, Shubhan. "Penanganan Covid-19 Dalam Pendekatan Kaidah Fikih Dan Ushul Fikih (Analisis Kebijakan Pembatasan Sosial Berskala Besar Dibidang Keagamaan).” Al-Adalah: Jurnal Hukum Dan Politik Islam 5, no. 2 (July 16, 2020): 100-122.

Sulastriyono, Sulastriyono. "Adat Law as An Alternative Option In Law Pluralism Perspective In Indonesia." Journal of Indonesian Adat Law (JIAL) 1, no. 1 (October 15, 2020): 34-62.

Tamanaha, Brian Z. "The Promise and Conundrums of Pluralist Jurisprudence." The Modern Law Review 82, no. 1 (January 2019): 159-79.

Werbner, Pnina, and Richard Werbner. "Adultery Redefined: Changing Decisions of Equity in Customary Law as 'Living Law' in Botswana." PoLAR: Political and Legal Anthropology Review 43, no. 1 (May 11, 2020): 136-52.

Windia, Wayan P., Sulistyowati Irianto, Chatarina Dewi Wulansari, Dominikus Rato, A Suriyaman Mustari Pide, Rosnidar Sembiring, Laksanto Utomo, et al. "Bunga Rampai APHA Indonesia: Melihat Covid-19 Dari Perspektif Hukum Adat." Journal of Indonesian Adat Law (JIAL) 1, no. 1 (2020): 373.

Wulansari, RR. Catharina Dewi. "The Role of The Government in The Recognition of Customary Rights to Achieve Economic Development of Customary Law Communities." Journal of Indonesian Adat Law (JIAL) 1, no. 1 (October 15, 2020): 109-45.

Wulansari, Rr Catharina Dewi, and Yenny Yorisca. "Persoalan-Persoalan Kontemporer Dalam Ilmu Hukum." Ajudikasi : Jurnal Ilmu Hukum 4, no. 1 (2020): 83-98.

Yunus, Ahyuni, and Ahmad Ali Muddin. "Penyelesaian Sengketa Tanah Ulayat Yang Telah Bersertifikat Berdasarkan Hukum Adat Malind-Anim." Jurnal Kertha Patrika 41, no. 3 (2019): 206.

Žemaitèlytė-Ivanavičè, Ingrida. "The Confrontation of Education and Customary Law At School: The Case Of Roma." Journal of Education Culture and Society 11, no. 2 (September 11, 2020): 68-81.

\section{Internet}

Abotsi, E. Kofi. "Customary Law and the Rule of Law." Arizona Journalof International \& Comparative Law 37, no. 2 (2020): 137-66.

Ackerman, Bruce. "The Emergency Constitution." Journal of Constitutional Law 1, no. Special Edition (2020): 9-63.

Aspan, Zulkifli, and Wiwin Suwandi. "Menjerat Kader, Melepas Partai Politik; Pertanggungjawaban Pidana Partai Politik Dalam Kasus Tindak Pidana Korupsi." Al-Adalah: Jurnal Hukum Dan Politik Islam 5, no. 1 (April 30, 2020): 57-78. https://doi.org/10.35673/ajmpi.v5i1.677. 
Aswar, Hasbi, Danial Bin Mohd. Yusof, and Rohana Binti Abdul Hamid.

"Conflict Between Hizb Ut-Tahrir And Islamic Civil Society In Indonesia:A Countermovement Approach.” Al-Adalah: Jurnal Hukum Dan Politik Islam 5, no. 2 (July 2020): 171-91. https://doi.org/10.35673/ajmpi.v5i2.892.

Barahamin, Andre. "Bongku Dan Pengabaian Hak Masyarakat Adat." mongabay.co.id, 2020.

Berman, Paul Schiff. The Oxford Handbook of Global Legal Pluralism. Oxford: Oxford University Press, 2020.

Bittar, Eduardo C. B. "Semiotics of Law, Juridicity and Legal System: Some Observations and Clarifications of a Theoretical Concept." International Journal for the Semiotics of Law 1, no. 1 (November 2020): 1-24. https://doi.org/10.1007/s11196-020-09797-4.

Bose, Neilesh, and Victor V. Ramraj. "Lex Mercatoria, Legal Pluralism, and the Modern State through the Lens of the East India Company, 1600-1757." Comparative Studies of South Asia, Africa and the Middle East 40, no. 2 (August 2020): 277-90. https://doi.org/10.1215/1089201X-8524204.

Britton-Purdy, Jedediah, David Singh Grewal, Amy Kapczynski, and K. Sabeel Rahman. "Building a Law-and-Political-Economy Framework: Beyond the Twentieth-Century Synthesis." Yale Law Journal 129, no. 6 (2020): 17861832.

Corrin, Jennifer. "Plurality and Punishment: Competition Between State and Customary Authorities in Solomon Islands." The Journal of Legal Pluralism and Unofficial Law 51, no. 1 (January 2019): 29-47. https://doi.org/10.1080/07329113.2018.1540121.

CORTÉS-NIETO, JOHANNA DEL PILAR. "Transnational Law and Development as a Means to Reshape States and Rights." Journal of Law and Society 47, no. 4 (November 2020): 694-701. https://doi.org/10.1111/jols.12264.

Dai, Xia. "Studies on the Legal Translation from the Perspective of Legal Pluralism." Theory and Practice in Language Studies 9, no. 8 (2019): 97377. https://doi.org/10.30564/ret.v2i3.870.

Disantara, Fradhana Putra. "Aspek Imunitas Dalam Penanganan Corona Virus Disease 2019." Istinbath: Jurnal Hukum 17, no. 1 (2020): 65-82. https://doi.org/https://doi.org/10.32332/istinbath.v17i1.2049.

__. "Pancasila Juga Volksgeist, Tanya Kenapa ?" In Filsafat Hukum Pancasila (Suatu Kajian Filsafat, Hukum, Dan Politik), edited by Irfa Ronaboyd and Fradhana Putra Disantara, 63-68. Jakarta Selatan: Kreasi Cendekia Pustaka, 2020.

- "Tanggung Jawab Negara Dalam Masa Pandemi Covid-19." Jurnal Cendekia Hukum 6, no. 1 (2020): 48-20. https://doi.org/http://doi.org/10.33760/jch.v6i1.262.

_. "The Large Scale Social Restrictions Policy For Handling The COVID19 Pandemic." Jurnal Pembaharuan Hukum 7, no. 2 (2020): 128-41. https://doi.org/http://dx.doi.org/10.26532/jph.v7i2.9429.

- "The Legitimacy of Circular Letter in Handling COVID-19 Pandemic." Rechtsidee 6, no. 2 (2020): 1-10. 
https://doi.org/10.21070/rechtsidee.2020.6.645.

Engelenhoven, Gerlov van. "From Indigenous Customary Law to Diasporic Cultural Heritage: Reappropriations of Adat Throughout the History of Moluccan Postcolonial Migration." International Journal for the Semiotics of Law, 2020, 1-27. https://doi.org/doi.org/10.1007/s11196-020-09781-.

Gharios, Georges. "Legal Pluralism and Un-Official Law in Lebanon: Evolution and Sustainable Development of Water." Water Policy 22, no. 3 (June 2020): 348-64. https://doi.org/10.2166/wp.2020.224.

Ghosh, Yashomati, and Anirban Chakraborty. "Secularism, Multiculturalism and Legal Pluralism: A Comparative Analysis Between the Indian and Western Constitutional Philosophy." Asian Journal of Legal Education 7, no. 1 (January 2020): 73-81. https://doi.org/10.1177/2322005819859674.

Ginsburg, Tom. “Authoritarian International Law?” American Journal of International Law 114, no. 2 (April 2020): 221-60. https://doi.org/10.1017/ajil.2020.3.

Haar, Dirk ter. Asas-Asas Dan Susunan Hukum. Edited by Soebakti Pesponoto. Jakarta: Balai Pustaka, 2017.

Haq, Hilman Syahrial. Pengantar Hukum Adat. Klaten: Lakeisha, 2020.

Insole, Christopher J. Kant and the Divine: From Contemplation to the Moral Law. New York: Oxford University Press, 2020.

Jany, Janos. Legal Traditions in Asia: History, Concepts and Laws. Cham: Springer Nature, 2020.

Jayus, Jaja Ahmad. Hukum Adat: Teori, Sejarah, Pengakuan Negara, Dan Yuriprudensi. Jakarta Selatan: Rajawali Press, 2020.

Jentoft, Svein, and Maarten Bavinck. "Reconciling Human Rights and Customary Law: Legal Pluralism in The Governance of Small-Scale Fisheries.” The Journal of Legal Pluralism and Unofficial Law 51, no. 3 (September 2019): 271-91. https://doi.org/10.1080/07329113.2019.1674105.

Johnson, Nevin. “Legality's Law's Empire.” Law and Philosophy 39, no. 3 (June 2020): 325-49. https://doi.org/10.1007/s10982-020-09374-7.

Kahraman, Filiz, Nikhil Kalyanpur, and Abraham L. Newman. "Domestic Courts, Transnational Law, and International Order." European Journal of International Relations 26, no. 1_suppl (September 2020): 184-208. https://doi.org/10.1177/1354066120938843.

Korson, Cadey, Sybille Poaouteta, and Gerard Prinsen. "Triangular Negotiations of Island Sovereignty: Indigenous and Customary Authorities - Metropolitan States - Local Metropolitan Authorities." Island Studies Journal 15, no. 1 (2020): 67-88.

Kuruk, Paul. Traditional Knowledge, Genetic Resources, Customary Law and Intellectual Property: A Global Primer. Cheltenham: Edward Elgar Publishing, 2020.

Ledvinka, Tomáš. "The Disenchantment of the Lore of Law: Jacob Grimm's Legal Anthropology Before Anthropology." The Journal of Legal Pluralism and Unofficial Law 52, no. 2 (May 2020): 203-26. https://doi.org/10.1080/07329113.2020.1755577.

Lemos, Miguel De. "Legal Pluralism and International Development: Introductory 
Notes on the Dialogue between The Two Concepts." Humanities and rights | global network journal 2, no. 1 (June 2020): 190-233.

https://doi.org/10.24861/2675-1038.v2i1.31.

Lubaale, Emma Charlene. "Legal Pluralism As a Lens Through Which to Understand The Role and Place of Tjms in International Criminal Justice." The Journal of Legal Pluralism and Unofficial Law 52, no. 2 (May 2020): 180-202. https://doi.org/10.1080/07329113.2020.1780387.

Lucy, William. "Access to Justice and the Rule of Law." Oxford Journal of Legal Studies 40, no. 2 (June 2020): 377-402. https://doi.org/10.1093/ojls/gqaa012. Mansur, Teuku Muttaqin, Sulaiman Sulaiman, and Hasbi Ali. "Adat Court in Aceh, Indonesia: A Review of Law." Jurnal Ilmiah Peuradeun 8, no. 2 (May 2020): 423. https://doi.org/10.26811/peuradeun.v8i2.443.

Marzuki, Peter Mahmud. Penelitiam Hukum. 13th ed. Jakarta: Kencana, 2017. Meerssche, Dimitri Van Den, and Geoff Gordon. " A New Normative Architecture' - Risk and Resilience as Routines of Un-Governance." Transnational Legal Theory 11, no. 3 (July 2020): 267-99. https://doi.org/10.1080/20414005.2020.1825036.

Menski, Werner F. Comparative Law in a Global Context: The Legal Systems of Asia and Africa. Comparative Law in a Global Context: The Legal Systems of Asia and Africa, Second Edition. 2nd ed. Cambridge: Cambridge University Press, 2006. https://doi.org/10.1017/CBO9780511606687.

Mulyono, Mulyono, Dewi Setyowati, and Kamarudin Kamarudin. "Tanggung Jawab Hukum Atas Pasien Gangguan Jiwa Yang Melarikan Diri Dari Ruang Rawat Inap Rumah Sakit." Al-Adalah: Jurnal Hukum Dan Politik Islam 3, no. 1 (2019): 56-65. https://doi.org/10.35673/ajmpi.v3i1.191.

Naso, Pedro, Erwin Bulte, and Tim Swanson. "Legal Pluralism in Post-Conflict Sierra Leone." European Journal of Political Economy 61 (January 2020): 1-21. https://doi.org/10.1016/j.ejpoleco.2019.101819.

Nielsen, Marianne O., and Karen Jarratt-Snider, eds. Traditional, National, and International Law and Indigenous Communities. Arizona: University of Arizona Press, 2020.

Osborne, Toby. The Routledge Handbook of Translation and Culture. Edited by Sue-Ann Harding and Ovidi Carbondell Cortés. The Routledge Handbook of Translation and Culture. New York, NY : Routledge, 2018. | Series:

Routledge handbooks in translation and interpreting studies: Routledge, 2018. https://doi.org/10.4324/9781315670898.

Pareke, JT, and Fahmi Arisandi. "PENGAKUAN MASYARAKAT HUKUM ADAT DAN PERLINDUNGAN WILAYAH ADAT DI KABUPATEN REJANG LEBONG.” Bina Hukum Lingkungan 4, no. 2 (April 2020): 313. https://doi.org/10.24970/bhl.v4i2.135.

Prasetio, Dicky Eko, Fradhana Putra Disantara, and Nadia Husna Azzahra. "Kitab Kutaramanawa Dharmasastra Dan Supremasi Konstitusi Jaman Majapahit.” beritajatim.com, 2020.

. "Menanti Legalisasi Desa Adat Sendi, Sampai Kapan?" mediajatim.com, 2020.

"Peradilan Adat Sendi: Mutiara Di Balik Tirai Hukum Negara." 
Gresnews.com, 2020.

Pratiwi, Putri Fransiska Purnama, Suprayitno, and Triyani. "Existence of Customary Law through Comparative Education between Dayak Ngaju Customary Law and National Law." Budapest International Research and Critics Institute (BIRCI-Journal) : Humanities 3, no. 2 (2020). https://doi.org/https://doi.org/10.33258/birci.v3i2.882.

Rahardjo, Satjipto. Membedah Hukum Progresif. Jakarta: Penerbit Buku Kompas, 2006.

Rato, Dominikus, Laksanto Utomo, I Gusti Agung Mas Rwa Jayantiari, Simona Bustami, Aartje Tehupeiory, Marlisa Ayu Trisia, Abdul Rahman Nur, et al. Kearifan Lokal Masyarakat Hukum Adat Dalam Mewujudkan Kedaulatan Pangan Ditengah Pandemi Covid 19. Edited by Ning Adiasih, C. Woro Murdiati R, and Rina Yulianti. Jakarta: Lembaga Studi Hukum Indonesia (LSHI), 2020. https://doi.org/10.46816/jial.v1i1.12.

Sabrow, Sophia. "Non-Enforcement as a Tool of Mediation in Pluralistic Societies." The Journal of Legal Pluralism and Unofficial Law 52, no. 2 (May 2020): 154-79. https://doi.org/10.1080/07329113.2020.1796296.

Samara, Angeliki. Beyond the Responsibility to Protect in International Law: An Ethics of Irresponsibility. New York: Routledge, 2020.

Sani, Hanisah Binte Abdullah. "State Law and Legal Pluralism: Towards an Appraisal." The Journal of Legal Pluralism and Unofficial Law 52, no. 1 (January 2020): 82-109. https://doi.org/10.1080/07329113.2020.1727726.

Saptiyulda, Erafzon. "Buka Dokumen HGU Untuk Tuntaskan Persoalan Tata Kelola Hutan." antaranews.com, 2019.

Schulz, Jennifer L. Mediation \& Popular Culture. New York: Routledge, 2020.

Shaw, Elizabeth. "Justice Without Moral Responsibility?" Journal of Information Ethics 28, no. 1 (2019).

Shodiq, Shubhan. "Penanganan Covid-19 Dalam Pendekatan Kaidah Fikih Dan Ushul Fikih (Analisis Kebijakan Pembatasan Sosial Berskala Besar Dibidang Keagamaan)." Al-Adalah: Jurnal Hukum Dan Politik Islam 5, no. 2 (July 2020): 100-122. https://doi.org/10.35673/ajmpi.v5i2.743.

Sinai, Yuval, and Benjamin Shmueli. Maimonides and Contemporary Tort Theory: Law, Religion, Economics, and Morality. Cambridge: Cambridge University Press, 2020.

Staubach, Peter G. The Rule of Unwritten International Law: Customary Law, General Principles, and World Order. Milton Park: Taylor \& Francis, 2020.

Sulastriyono, Sulastriyono. "Adat Law as An Alternative Option In Law Pluralism Perspective In Indonesia.” Journal of Indonesian Adat Law (JIAL) 1, no. 1 (October 2020): 34-62. https://doi.org/10.46816/jial.v1i1.16.

Tamanaha, Brian Z. "The Promise and Conundrums of Pluralist Jurisprudence." The Modern Law Review 82, no. 1 (January 2019): 159-79. https://doi.org/10.1111/1468-2230.12393.

Tusseau, Guillaume, ed. Debating Legal Pluralism and Constitutionalism: New Trajectories for Legal Theory in the Global Age. New York: Springer Nature, 2020.

Werbner, Pnina, and Richard Werbner. “Adultery Redefined: Changing Decisions 
of Equity in Customary Law as 'Living Law' in Botswana." PoLAR:

Political and Legal Anthropology Review 43, no. 1 (May 2020): 136-52. https://doi.org/10.1111/plar.12344.

Windia, Wayan P., Sulistyowati Irianto, Chatarina Dewi Wulansari, Dominikus Rato, A Suriyaman Mustari Pide, Rosnidar Sembiring, Laksanto Utomo, et al. "Bunga Rampai APHA Indonesia: Melihat Covid-19 Dari Perspektif Hukum Adat.” Journal of Indonesian Adat Law (JIAL) 1, no. 1 (2020): 373. https://doi.org/10.46816/jial.v1i1.1.

Wulansari, RR. Catharina Dewi. "The Role of The Government in The Recognition of Customary Rights to Achieve Economic Development of Customary Law Communities." Journal of Indonesian Adat Law (JIAL) 1, no. 1 (October 2020): 109-45. https://doi.org/10.46816/jial.v1i1.18.

Wulansari, Rr Catharina Dewi. Hukum Adat Indonesia - Suatu Pengantar. 4th ed. Bandung: PT Refika Aditama, 2016.

Wulansari, Rr Catharina Dewi, and Yenny Yorisca. "Persoalan-Persoalan Kontemporer Dalam Ilmu Hukum.” Ajudikasi : Jurnal Ilmu Hukum 4, no. 1 (2020): 83-98.

Yunus, Ahyuni, and Ahmad Ali Muddin. "Penyelesaian Sengketa Tanah Ulayat Yang Telah Bersertifikat Berdasarkan Hukum Adat Malind-Anim.” Jurnal Kertha Patrika 41, no. 3 (2019): 206. https://doi.org/10.24843/KP.2019.v41.i03.p0.

Žemaitėlytė-Ivanavičè, Ingrida. "The Confrontation of Education and Customary Law At School: The Case Of Roma." Journal of Education Culture and Society 11, no. 2 (September 2020): 68-81. https://doi.org/10.15503/jecs2020.2.68.81. 